Utah State University

DigitalCommons@USU

$5-1982$

\title{
Population Characteristics and Movement Patterns of Cougars in Southern Utah
}

Thomas P. Hemker

Utah State University

Follow this and additional works at: https://digitalcommons.usu.edu/etd

Part of the Life Sciences Commons

\section{Recommended Citation}

Hemker, Thomas P., "Population Characteristics and Movement Patterns of Cougars in Southern Utah" (1982). All Graduate Theses and Dissertations. 7119.

https://digitalcommons.usu.edu/etd/7119

This Thesis is brought to you for free and open access by the Graduate Studies at DigitalCommons@USU. It has been accepted for inclusion in All Graduate Theses and Dissertations by an authorized administrator of DigitalCommons@USU. For more information, please contact digitalcommons@usu.edu.

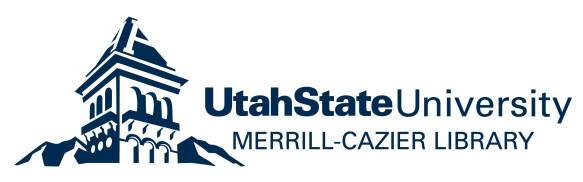




\title{
POPULATION CHARACTERISTICS AND MOVEMENT PATTERNS
}

\section{OF COUGARS IN SOUTHERN UTAH}

by

\author{
Thomas P. Hemker
}

A thesis submitted in partial fulfillment of the requirements for the degree

of

MASTER OF SCIENCE

in

Wildlife Ecology

UTAH STATE UNIVERSITY

Logan, Utah 


\section{ACKNOWLEDGMENTS}

This study was funded by the Utah Division of Wildlife Resources (UDWR) and administered by the Utah Cooperative Wildlife Research Unit: Utah Division of Wildlife Resources, Utah State University, U.S. Fish and Wildife Service, and Wildlife Management Institute cooperating. My major professor, Dr. Fred Lindzey, provided large amounts of his time helping in the development and completion of my thesis program. Bruce Ackerman also contributed much time and effort to my research. Arnold Button provided indispensable help as the houndsman and chief technician on the project. Tom Rettberg of the UDWR was our pilot and flew many long days for us. The Button and Coleman families, Mason Reid, Fred Van Dyke, Kurt Johnson, Dan Shepardson, Ken Parr, Marilyn Hemker, Barbara Blakesley, Richard Gruneig, Leon Cox, and Rock Peters also assisted with the fieldwork. Floyd Coles, Jim Guyman, Norm Hancock, Clair Jensen, and Ted Gardiner of the UDWR provided important support and advice. My committee members, Mr. Floyd Coles, Dr. Keith Dixon, and Dr. Fred Knowlton, gave valuable criticism of the manuscript. Cooperation was provided by the U.S.D.A. Forest Service and the Bureau of Land Management. I am especially grateful to my wife, Marilyn, for her he1p and encouragement throughout my graduate program. 
ACKNOWLEDGMNTS

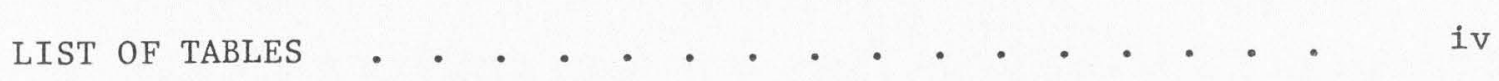

LIST OF FIGURES • • • • • • • • • • • • • • • • v v

ABSTRACT • . . . . . . . . . . . . . . . v vii

INTRODUCTION • • • • • • • • • • • • • • • • • 1

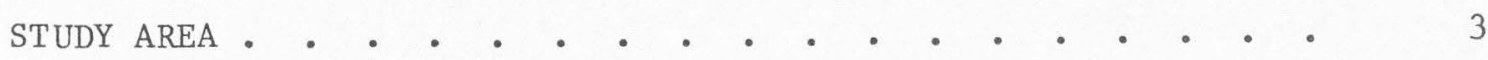

METHODS • • • • • • • • • • • • • • • • • • • 6

RESULTS • • • • • • • • • • • • • • • • • • • •

DISCUSSION • • • • • • • • • • • • • • • • • • • • •

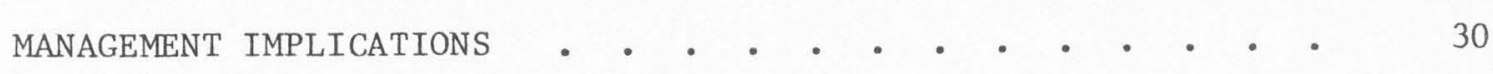

LITERATURE CITED • • • • • • • • • • • • • • • • • 33

APPENDICES • • • • • • • • • • • • • • • • • • 36 


\section{LIST OF TABLES}

Table

1. Sex, age, and relocation information for 22 cougars captured on the Boulder-Escalante study area, Utah, 1979-1981

2. Estimates of winter cougar population size and composition on the Boulder-Escalante study area, Utah, 1979-1981

3. Cougar population composition and densities reported in North America.

4. Patterns of home area use for five resident cougars on the Boulder-Escalante study area, Utah, 1979-1981.

5. Mean and maximum airline distance $(\mathrm{km})$ moved from an initial relocation to relocations 1,2 , and 7 days later on the Boulder-Escalante study area, Utah, 1979-1981 . .

6. Resident cougar home area sizes $\left(\mathrm{km}^{2}\right)$ and overlap characteristics reported in North America . . . . .

7. Physical measurements made of 22 cougars at capture on the Boulder-Escalante study area, Utah, 1979-1981 . .

8. One-day movement patterns of cougars after capture compared to non-capture movement patterns on the Boulder-Escalante study area, Utah, 1979-1981

9. Details of nine dead cougars found on the BoulderEscalante study area, April 1979 to July 1981 • . .

10. Variables associated with scratches and female scat mounds observed on the Boulder-Escalante study area, Utah, 1979-1981 


\section{LIST OF FIGURES}

Figure

1. Monthly mean elevations (m) for five resident cougars on the Boulder-Escalante study area, Utah, 1979-1981 . . .

2. Home areas of resident cougars on the Boulder-Escalante study area, Utah, 1979-1981

3. Time intervals 22 cougars were tracked using radiotelemetry on the Boulder-Escalante study area, Utah, 1979-1981

4. Lines connecting capture and relocation sites of transient female cougar F50 on the Boulder-Escalante study area, Utah, from 6 December 1979 to 28 November 1980

5. Capture and relocation sites, seasonal home areas, and seasonal centers of activity for resident female cougar F80 on the Boulder-Escalante study area, Utah, from 28 October 1979 to 19 April 1980 . . . . . . .

6. Capture and relocation sites, seasonal home areas, and seasonal centers of activity for resident female cougar F90 on the Boulder-Escalante study area, Utah, from 24 January 1980 to $30 \mathrm{July} 1981$. . . . . . . . .

7. Capture and relocation sites, seasonal home areas, and seasonal centers of activity for resident female cougar F130 on the Boulder-Escalante study area, Utah, from 21 April 1979 to 17 July 1981 . . . . . • • . .

8. Capture and relocation sites, seasonal home areas, and seasonal centers of activity for resident female cougar F150 on the Boulder-Escalante study area, Utah, from 24 April 1979 to 14 April 1981 . . . . . . . . .

9. Capture and relocation sites, seasonal home areas, and seasonal centers of activity for resident male cougar M180 on the Boulder-Escalante study area, Utah, from 4 June 1980 to 28 July 1981 • . . . . • . . .

10. Lines connecting capture and relocation sites of transient female cougar F190 on the Boulder-Escalante study area, Utah, from 17 June 1980 to $30 \mathrm{July} 1981$ 


\section{LIST OF FIGURES (Continued)}

Figure

11. Lines connecting capture and relocation sites of transient/resident female cougar F200 on the BoulderEscalante study area, Utah, from 27 February 1981 to 30 July 1981

12. Lines connecting capture and relocation sites of transient/resident female cougar F220 on the BoulderEscalante study area, Utah, from 4 May 1981 to $30 \mathrm{July}$ 1981

13. Monthly mean elevation (m) including range and standard deviation for resident female cougar F80 on the BoulderEscalante study area, Utah, 1979-1980 . . . . . .

14. Monthly mean elevation (m) including range and standard deviation for resident female cougar F90 on the BoulderEscalante study area, Utah, 1980-1981

15. Monthly mean elevation (m) including range and standard deviation for resident female cougar F130 on the BoulderEscalante study area, Utah, 1979-1981 . . . . . .

16. Monthly mean elevation (m) including range and standard deviation for resident female cougar F150 on the BoulderEscalante study area, Utah, 1979-1981 . . . . . .

17. Monthly mean elevation (m) including range and standard deviation for resident male cougar M180 on the BoulderEscalante study area, Utah, 1980-1981 . . . . . .

18. Home area overlap of resident female F90 and her female cub FC 92 on the Boulder-Escalante study area, Utah, 15 February 1980 to 19 January 1981 . . . . . . . .

19. Home area overlap of resident female F130 and her male cub MC 131 on the Boulder-Escalante study area, Utah, 22 April 1979 to 6 September 1979 . . . . . . . .

20. Home area overlap of resident female F150 and her female cub FC 151 on the Boulder-Escalante study area, Utah, 7 September 1979 to 30 March 1980 . . . . . . . 


\author{
ABSTRACT \\ Population Characteristics and Movement Patterns \\ of Cougars in Southern Utah \\ by \\ Thomas P. Hemker, Master of Science \\ Utah State University, 1982
}

Major Professor: Dr. Fredrick G. Lindzey

Department: Wildlife Science

Movements of 22 cougars (Felis concolor) were monitored by radiotelemetry between January 1979 and July 1981 in southern Utah. The population, composed of resident, transient, and juvenile cougars, remained relatively constant in size for 3 years. Densities $(0.4-0.5$ cougars $/ 100 \mathrm{~km}^{2}$ ) were considerably lower than has been reported elsewhere. Average annual home area size of resident females $\left(685 \mathrm{~km}^{2}\right)$ and a single resident male $\left(826 \mathrm{~km}^{2}\right)$ were substantially larger than other home area sizes reported. Home areas of resident females overlapped and resident male home areas may have overlapped as we11. Despite the degree of overlap observed, with the exception of family groups, close spatial associations were rare. Dispersal of cubs appeared to be independent of adult resident density. Density of resident cougars appears to be regulated by a social pattern based on land tenure but limited by abundance of mule deer, their principal prey on this study area. The relative vulnerability to hunting of different cougar cohorts is discussed. 


\section{INTRODUCTION}

The controversial status and elusive nature of the cougar (Felis concolor) has hampered gathering ecological information on this species. Before work in Idaho by Hornocker $(1969,1970)$ and Seidensticker et al. (1973), little published data on cougar population characteristics and movement patterns existed. They concluded that an adult cougar population consisted of breeding residents and a variable number of transients that established residency and bred only when sites were provided by removal of residents. In addition, they concluded that the social organization maintained the population below a level set by prey.

More recent, but less detailed information from Nevada (Ashman 1981), California (Sitton 1977, Koford 1978, Kutilek et a1. 1980), Arizona (Shaw 1977, 1979, 1980), Colorado (Currier et al. 1977), and British Columbia (Dewar and Dewar 1976), however, has yielded conflicting results. While differences in density and home area size might be expected under varying environmental conditions, differences in population composition and dispersion patterns are less easily explained. Shaw (1977), Ashman (pers. comm.), Sitton (1977) and Kutilek et al. (1980) reported resident males using overlapping areas al though Hornocker $(1969,1970)$ and Seidensticker et al. (1973) did not. Similarly, female overlap was recorded by the Idaho workers but not by personnel in California. In contrast to other investigators, Kutilek et a1. (1980) reported more resident males than females and no transients in their study population. 
Further investigation of these population characteristics, possible reasons for their variability, and their effects on the social organization of the cougar is necessary to provide a firm basis for management. This report describes the population characteristics and movement patterns of a cougar population in south-central Utah. A co-worker (Ackerman 1982) examined food habits and energetics of the cougars in this area. 
STUDY AREA

The vegetatively and topographically diverse study area includes about $4500 \mathrm{~km}^{2}$ of Garfield and Kane Counties in south-central Utah. Elevation of the area, which includes the southern peaks and slopes of the Boulder and Escalante mountains, the Canaan Mountain, and adjacent canyonlands and desert, ranges from about 1350 to $3355 \mathrm{~m}$. Precipitation occurs primarily as rain in August and September and moderate snowfall in winter. Annual precipitation in the town of Escalante at $1769 \mathrm{~m}$ averages $28.3 \mathrm{~cm}$ (U.S. Department Commerce 1979). About $18 \mathrm{~cm}$ fall at the lower elevations and as much as $60 \mathrm{~cm}$ on the higher mountain plateaus. Average daily temperature in Escalante in January is $-2.8^{\circ} \mathrm{C}$ and in Ju1y $24.5^{\circ} \mathrm{C}$.

The study area supports several major vegetation types. Desert grass and shrub communities with a sparse overstory of pinyon pine (Pinus edulis) and juniper (Juniperus osteosperma) predominate between 1350 and $1800 \mathrm{~m}$. River canyons within these communities support riparian vegetation which includes Fremont cottonwood (Populus fremontii) and willow (Salix sp.). Dense pinyon-juniper woodlands interspersed with sagebrush (Artemisia tridentata) flats between 1800 and $2400 \mathrm{~m}$ include the major big game wintering areas. Between 2400 and $2700 \mathrm{~m}$, ponderosa pine (Pinus ponderosa) and oakbrush (Quercus gambelii) dominate. Engelmann spruce (Picea engelmannii) and quaking aspen (Populus tremuloides) interspersed with grassy openings dominate vegetation above $2700 \mathrm{~m}$. The study area also includes extensive areas of bare sandstone below $2400 \mathrm{~m}$. 
About a third of the study area boundary abuts habitat that is less suitable for cougar. To the south and east large areas of open rocky desert with limited water and prey probably preclude the presence of resident cougars. To the northwest, the treeless plains of Parker Mountain offer marginal cover for hunting by cougars.

Mule deer (Odocoileus hemionus) and elk (Cervus elaphus) are the major big game species present on the area although a small number of desert bighorn sheep (Ovis canadensis nelsoni) are present along the lower sections of the Escalante River. Approximately 5000 mule deer and 200 elk were present during the study (Ackerman 1982). Black-tailed jackrabbits (Lepus californicus), yellow-bellied marmots (Marmota flaviventris), rock squirrels (Spermophilus variegatus) and coyotes (Canis latrans) are also common on the study area. About 6180 cattle graze annually on Forest Service and Bureau of Land Management 1ands on the study area between June and October. Nearly all calves were born in ranch yards or on desert ranges not used intensively by cougars. Human population on the study area was about 800 , located primarily in the towns of Escalante and Boulder. Recreational use of the area was light because of its isolated location. Major land uses included livestock grazing, timber harvesting, and energy exploration and development. These activities created an extensive road and trail system with relatively few areas farther than $5 \mathrm{~km}$ from a road, simplifying the location of sign. These areas were easily traversed by cougars and none were large enough to totally contain the relatively large cougar home areas observed. Cougars were observed, however, to quickly cross even these areas. 
As many as 18 cougars were taken annually in the late 1960's. Based on harvest records (Utah Division of Wildlife Resources 1980) and communications with local hunters, we estimated that 5 to 10 cougars were harvested annually between 1970 and 1979. The study area was closed to cougar hunting by the Utah Wildlife Board in April 1979. Hunting, however, continues on the periphery of the study area and 9 cougars were harvested during the 1979-80 season on the northern slopes of the Boulder-Escalante Mountains. 
METHODS

Field work began in January 1979 and continued until July 1981. Size and composition of the study population was determined by systematically searching the entire study area for evidence of cougars. Tracks, scats, needle and soil mounds covering scats, scratches made by male cougars, and kills were the major types of sign encountered. An average of three observers was present on the study area including a full-time houndsman. Radio-telemetry relocations and tracks of cougars marked by surgical removal of a toe allowed us to better interpret sign. Population estimates were made during the winter when snow tracking made locating sign easier. Information gathered during the rest of the year was used to refine the estimates.

Cougars were captured using methods similar to those described by Hornocker (1970). Trained dogs were used to track and tree or bay cougars. They were then immobilized with a 1.0:0.15 mixture of ketamine hydrochloride (Vetalar, Ketaset) and xylazine hydrochloride (Rompun) (Clark et al. 1979) administered by a $\mathrm{CO}^{2}$ pistol-fired syringe. Body measurements were made and dental characteristics recorded to estimate age using criteria established in Nevada (D. Ashman, pers. comm.). We also checked females for evidence of recent lactation. Ears were tattooed with an identification number and numbered ear tags attached. A collar containing a motion-sensitive radio transmitter was attached to each cougar. Cubs were fitted with drop-off collars similar to those described by Garcelon (1977). While this ensured the safety 
of the cub if it outgrew Lhe collar, we found relatively little neck growth in females after 6 months of age (Appendix B).

We attempted to relocate all radio-tagged cougars at least once a week from a fixed-wing aircraft. Selected cougars were also relocated several times a week from the ground to obtain more detailed information on movements, intraspecific associations, activity patterns, and frequency of kills. Relocations were assigned Universal Transverse Mercator coordinates recorded to the nearest $0.1 \mathrm{~km}$. We subjectively evaluated the quality of each relocation. We defined Type 1,2 and 3 relocations as those where we could place the cougar within an area $0.5,0.5$ to 1.5 , and greater than $1.5 \mathrm{~km}$ in diameter, respectively. We use the term home area (Seidensticker et al. 1973) to describe the area encompassed by lines connecting the outermost relocation points for a resident cougar. This area is only an estimate of actual area used but it allowed comparison between our results and those of other investigators. Seasonal periods (winter and non-winter) were delineated on the basis of annual weather characteristics including snowfa11, snow depth and temperature.

When possible, centers of activity (Hayne 1949), mean elevation, and mean length of activity radii (Dice and Clark 1953) were calculated for each cougar for each seasonal period. Linear distance moved was calculated from one relocation to those relocations made 1,2 , and 7 days later. Only Type 1 and 2 relocations separated by full nocturnal activity periods were used in this calculation. Additionally, relocations 1 day after a cougar was treed, 3 days after it was treed and handled and 2 weeks after a capture and toe removal were omitted from analyses. Cougars generally localized their movements after capture, 
presumably to recover from any minor injuries suffered in the capture (Appendix $C$ ). When more than one relocation was made in a given day only the first relocation was used in analyses. A randomization test (Green 1977) and Student's t test were used to test for differences between means.

Residents were defined as adult cougars that showed site attachment (continuous use of a predictable area for 6 months or more). We assumed cubs had dispersed when they left the maternal home area. Cougars, other than family groups, located less than $1 \mathrm{~km}$ apart were recorded as in association.

To determine if males made scratches randomly we established three transects in each of three different topographic types. Each transect (Appendix G) was located within the adult male's home area. For each scratch observed, we recorded whether it was associated with a kill, a reused site, included a scat, as well as slope of the site, distance from a tree or rock outcrop, and type of tree or rock outcrop. To serve as a control population, 200 trees on each transect were randomly sampled and size ( $\mathrm{dbh}$ and height) and dominance estimated. A dominant tree was defined as a tree larger and higher than other visible trees. Average trees and understory trees were similar to, and smaller than other trees, respectively. 
RESULTS

Twenty-two cougars were captured or relocated a total of 1806 times (Table 1, Appendix A). Seventy-eight percent of the relocations were of Type 1 or Type 2 quality, while 20 percent were Type 3 . The remaining 2 percent were tracks or collar recoveries for which the time the cougar was present at the site was uncertain. Seventy-two percent of the relocations were made from the ground and the remainder from fixed-wing aircraft. Nine percent of the relocations were made at night.

\section{Population characteristics}

Our estimates of numbers, density, and composition of the cougar population remained relatively constant for three winters (Tables 2, 3). Resident females $(N=5-6)$ outnumbered resident males $(N=1-2)$ and few transients $(\mathrm{N}=1-2)$ were present. One resident female (F210) died, and another resident female (F80) was not located on the study area during the last year of the study. The appearance and subsequent site attachment of two transient females (F200 and F220), however, kept the number of resident females constant.

None of the cougars classified as transients (Table 1) reproduced, whereas each of the residents did. Two female cougars (F200 and F220), initially classified as transients when they immigrated into the study area, were later classified as residents when they showed site attachment and presumably bred. Although both were observed for only 5 months, the fact that they were using an area no longer occupied by a 
Table 1. Sex, age, and relocation information for 22 cougars captured on the Boulder-Escalante study area, Utah, 1979-1981.

\begin{tabular}{|c|c|c|c|c|c|}
\hline $\begin{array}{l}\text { Number } \\
\text { and sex }\end{array}$ & $\begin{array}{c}\text { Capture } \\
\text { date }\end{array}$ & Age ${ }^{b}$ & Status & $\begin{array}{l}\text { Months } \\
\text { radio } \\
\text { tracked }\end{array}$ & $\begin{array}{l}\text { Number of } \\
\text { captures and/or } \\
\text { relocations }\end{array}$ \\
\hline F130 & 21 Apr 79 & $7-9$ yr & Resident & 27 & 157 \\
\hline MC131 & 22 Apr 79 & $1978 \mathrm{cub}$ & & 5 & 35 \\
\hline F150 & 24 Apr 79 & $5-6$ yr & Resident & $22^{c}$ & 266 \\
\hline FC151 & 7 Sep 79 & $1978 \mathrm{cub}$ & & 4 & 116 \\
\hline MC152 & $5 \mathrm{Feb} 80$ & $1978 \mathrm{cub}$ & & 9 & 54 \\
\hline C153 & $8 \mathrm{Feb} 81$ & $1980 \mathrm{cub}$ & & 4 & 18 \\
\hline \multicolumn{6}{|l|}{ F80 d } \\
\hline FC81 & 28 Sep 79 & $1978 \mathrm{cub}$ & & 11 & 55 \\
\hline F50 & 6 Dec 79 & $2 \mathrm{yr}$ & Transient & 12 & 90 \\
\hline F70 & $14 \mathrm{~J}$ an 80 & $3-4$ yr & Resident & $<1_{c}^{c}$ & 13 \\
\hline FC 71 & $14 \operatorname{Jan} 80$ & 1979 cub & & $6^{c}$ & 41 \\
\hline F90 & $24 \mathrm{Jan} 80$ & $3-4$ yr & Resident & 18 & 227 \\
\hline FC91 & $17 \mathrm{Feb} 80$ & $1979 \mathrm{cub}$ & & 17 & 182 \\
\hline $\mathrm{FC} 92$ & $15 \mathrm{Feb} 80$ & 1979 cub & & $11^{\mathrm{c}}$ & 141 \\
\hline MC93 & 16 Feb 80 & 1979 cub & & 17 & 157 \\
\hline M180 & 4 Jun 80 & $3-4$ yr & Resident & 14 & 82 \\
\hline F190 & 17 Jun 80 & 1978 cub & Transient $_{f}^{e}$ & 13 & 47 \\
\hline F200 & 27 Feb 81 & $2 \mathrm{yr}$ & Trans/Res ${ }^{1}$ & 5 & 36 \\
\hline F210 & 7 Mar 81 & $7-9$ yr & Resident & & 1 \\
\hline FC211 & 20 Mar 81 & $1980 \mathrm{cub}$ & & 4 & 34 \\
\hline FC212 & 2 Mar 81 & 1980 cub & & 3 & 28 \\
\hline MC213 & 28 May 81 & 1980 cub & & 1 & 13 \\
\hline F220 & 4 May 81 & $2 \mathrm{yr}$ & Trans/Res ${ }^{ \pm}$ & 3 & 13 \\
\hline
\end{tabular}

Total

1806

$\mathrm{a}_{\mathrm{M}=\mathrm{male}}, \mathrm{F}=$ female, $\mathrm{C}=\mathrm{cub}$.

${ }^{b}$ Estimated at capture.

$\mathrm{c}_{\text {Transmitter inoperable, but animal known to be present for }}$ additional time (see Appendix A). text).

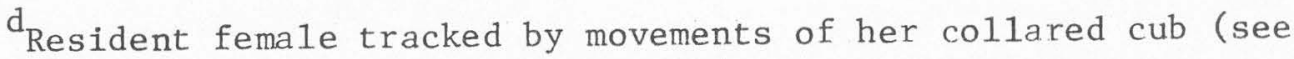

erphaned cub raised and released.

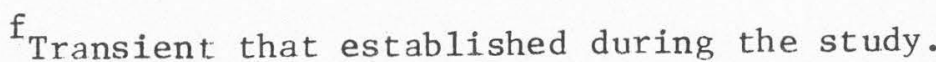


Table 2. Estimates of winter cougar population size and composition on the Boulder-Escalante study area, Utah, 1979-1981.

\begin{tabular}{lccccc}
\hline Winter & $\begin{array}{c}\text { Resident } \\
\text { males }\end{array}$ & $\begin{array}{c}\text { Resident } \\
\text { females }\end{array}$ & Juveniles & Transients & Total \\
\hline $1978-79$ & $2^{\mathrm{a}}$ & 6 & $7^{\mathrm{a}}$ & $?$ & $15^{\mathrm{a}}$ \\
$1979-80$ & 1 & 6 & 14 & 1 & 22 \\
$1980-81$ & 1 & $5^{\mathrm{b}}$ & 11 & $2^{\mathrm{c}}$ & 19 \\
\hline
\end{tabular}

${ }^{a}$ Possibly more present.

${ }^{\mathrm{b}}$ F80 not present. $\mathrm{F} 210$ found dead March 1981.

${ }^{c}$ Newly established resident females, F200 and F220 (see text).

resident female who had died suggested that they were taking advantage of a vacant resident site. Both of these females associated briefly (2-3 days) with the resident male 4 months after observation began and 3 months after the original resident female died, suggesting they bred.

We monitored seven litters of cubs on the study area and have records of three others in the vicinity. Al1 litters were estimated to have been born between September and November. Robinette et al. (1961) concluded, from examination of records of hunter-killed cougars in Nevada and Utah, that most cubs were born from July to September and Seidensticker et a1. (1973) reported the majority of cubs were born in the spring in northern Idaho. On our study area, about half of the resident females gave birth to cubs each year. The average interval between breeding was not determined, but F150 had cubs 2 years after the first litter we observed was born, though none of the cubs survived 
Table 3. Cougar population composition and densities reported in North America.

\begin{tabular}{|c|c|c|c|c|c|c|c|c|}
\hline \multirow{2}{*}{ Location } & \multicolumn{2}{|c|}{ Resident } & \multirow{2}{*}{ Juveniles } & \multirow{2}{*}{ Transients } & \multirow{2}{*}{$\begin{array}{c}\text { Total } \\
\text { population }\end{array}$} & \multirow{2}{*}{$\begin{array}{c}\text { Annual total } \\
\text { population } \\
\text { density } \\
\text { (cougar } / 100 \mathrm{~km}^{2} \text { ) }\end{array}$} & \multirow{2}{*}{$\begin{array}{c}\text { Annual } \\
\text { resident } \\
\text { density } \\
\left(\text { cougar } / 100 \mathrm{~km}^{2}\right)\end{array}$} & \multirow{2}{*}{ Source } \\
\hline & Males & Females & & & & & & \\
\hline Utah & $1-2$ & 6 & $7-14$ & $0-2$ & $17-22$ & $0.4-0.5^{\mathrm{a}}$ & $0.2^{c}$ & This study. \\
\hline Idaho & 3 & $2-6$ & $1-7$ & $0-5$ & $6-21$ & $2.1-7.4^{b}$ & $1.8-3.2^{b}$ & $\begin{array}{l}\text { Seidensticker } \\
\text { et a1. (1973) } \\
\text { Hornocker } \\
(1969,1970)\end{array}$ \\
\hline Nevada & 4 & $6-7$ & $8-10$ & $3-4$ & $21-25$ & $1.4-1.6$ & $0.6-0.7$ & Ashman (1976) \\
\hline Colorado & & & & & & $1.7-3.3$ & & $\begin{array}{l}\text { Currier et al. } \\
(1977)\end{array}$ \\
\hline Arizona & 2 & 7 & 8 & $0-2$ & $17-19$ & $3.2-3.5$ & 1.6 & Shaw (1977) \\
\hline California & & & & & & $3.5-4.4$ & & Sitton (1977) \\
\hline California & & & & & & $1.5-3.3$ & & $\begin{array}{l}\text { Kutilek et al. } \\
\quad(1980)\end{array}$ \\
\hline
\end{tabular}

\footnotetext{
a Mean non-winter density 1.1 , winter density 0.6 .

binter density.

Mean non-winter density 0.2 , mean winter density 0.4 .
} 
longer than 7 months. F130 was not observed to have cubs for $1-1 / 2$ years after her 1978 1itter dispersed. The size of the eight litters we observed before they were 6 months of age was 2.8. Robinette et al. (1961) reported an average of 3.0 and Hornocker (1970) 2.6 cubs per litter. Among 14 cubs we sexed, 37 percent were males.

We observed the dispersal of three litters of cubs in 1980 and two in 1981, totaling 12 cubs. Dispersal occurred during the cubs' second winter or spring when they were 16 to 19 months of age. Three of the cubs that dispersed in 1980 carried functioning radio-collars at the time, and were last relocated 6 to $44 \mathrm{~km}$ from their respective maternal home areas. The subsequent loss of radio contact with these cubs, even with extensive aerial searches up to $110 \mathrm{~km}$ from the study area, suggested that they dispersed long distances. One cub marked only by tattoos and ear tags was killed $35 \mathrm{~km}$ from its maternal home area at about 2 years of age. In addition, three of the cubs that dispersed in 1981 had functioning radio-collars at dispersal and were last relocated 10 to $25 \mathrm{~km}$ from their maternal home areas.

Six dead cubs and three dead adult cougars were found on the study area (Appendix F). All these animals probably died of causes unrelated to hunting, and except for one adult probably died during the study period. Four of the cubs died when less than 1 year old, and presumably were dependent on their mothers for food. Two others were about 1.5 years of age and may have been newly independent. The three adult cougars were $2,3-4$, and 5-6 years of age, respectively.

\section{Home area characteristics}

Home area size varied widely among individual cougars (Tables 4, 5, 
Table 4. Patterns of home area use for five resident cougars on the Boulder-Escalante study area, Utah, 1979-1981.

\begin{tabular}{|c|c|c|c|c|c|c|c|c|}
\hline Cougar & Year & Season $^{a}$ & $\begin{array}{c}\text { Seasonal } \\
\text { home area }\end{array}$ & $\begin{array}{c}\text { Total } \\
\text { home area }\end{array}$ & $\frac{\bar{x}}{\text { elevation }(\mathrm{m})^{\mathrm{b}}}$ & $\begin{array}{c}\overline{\mathrm{x}} \\
\text { activity }\end{array}$ & & $\begin{array}{l}\text { Distance } \\
\text { from }\end{array}$ \\
\hline & & & & & & & $\mathrm{CA}$ & to $\mathrm{CA}(\mathrm{km})^{\mathrm{C}}$ \\
\hline \multirow[t]{2}{*}{ F $80 \mathrm{~d}$} & 1979 & nw & 359 & 458 & 2221 & 9.2 & & \\
\hline & $1979-80$ & w & & & 1870 & & & 16.2 \\
\hline \multirow[t]{4}{*}{ F90 } & $1979-80$ & W & 157 & 432 & 2210 & 6.1 & & \\
\hline & 1980 & nw & 256 & & 2753 & 5.6 & & 11.2 \\
\hline & $1980-81$ & w & 149 & & 2221 & 7.5 & & 8.8 \\
\hline & 1981 & $\mathrm{p}$ & & & 2880 & & & \\
\hline \multirow[t]{5}{*}{ F130 } & 1979 & nw & 556 & 1454 & 1634 & 11.7 & & \\
\hline & $1979-80$ & w & 421 & & 1890 & 11.1 & & 18.6 \\
\hline & 1980 & nw & 399 & & 1664 & 14.5 & & 13.2 \\
\hline & $1980-81$ & w & 205 & & 1952 & 7.1 & & 18.7 \\
\hline & 1981 & $\mathrm{p}$ & & & 1835 & & & \\
\hline \multirow[t]{4}{*}{ F150 } & 1979 & $n w_{e}$ & 278 & 396 & 2747 & 6.3 & & \\
\hline & $1979-80$ & $w^{e}$ & 100 & & 2212 & 5.2 & & 10.8 \\
\hline & 1980 & nw & 232 & & 2824 & 5.4 & & 10.0 \\
\hline & $1980-81$ & w & 148 & & 2429 & 6.2 & & 5.3 \\
\hline \multirow[t]{3}{*}{ M1 80} & 1980 & nw & 573 & 826 & 2766 & 9.4 & & \\
\hline & $1980-81$ & w & 503 & & 2350 & 8.9 & & 5.9 \\
\hline & 1981 & $\mathrm{p}$ & & & 2617 & & & \\
\hline
\end{tabular}

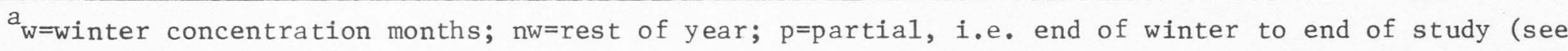
text).

${ }^{b}$ All mean winter elevations were significantly different $(p<.01)$ than mean non-winter elevations. ${ }^{c}$ Distance between successive centers of activity.

d Data for this female provided by movements of her collared cub (see text).

${ }^{\mathrm{e}}$ Collar non-functional for 1 month of this 4 -month period. 
Table 5. Mean and maximum airline distance $(\mathrm{km})$ moved from an initial relocation to relocations 1 , 2 , and 7 days later on the Boulder-Escalante study area, Utah, 1979-1981.

\begin{tabular}{|c|c|c|c|c|c|c|}
\hline Cougar & $\begin{array}{c}\overline{\mathrm{x}} \text { distance } \\
\text { moved }(\mathrm{km}) \\
\text { Day } 1\end{array}$ & $\begin{array}{c}\text { Maximum } \\
\text { distance } \\
(\mathrm{km})\end{array}$ & $\begin{array}{c}\overline{\mathrm{x}} \text { distance } \\
\text { moved }(\mathrm{km}) \\
\text { Day } 2\end{array}$ & $\begin{array}{l}\text { Maximum } \\
\text { distance } \\
\quad(\mathrm{km})\end{array}$ & $\begin{array}{c}\overline{\mathrm{x}} \text { distance } \\
\text { moved }(\mathrm{km}) \\
\text { Day } 7\end{array}$ & $\begin{array}{l}\text { Maximum } \\
\text { distance } \\
\quad(\mathrm{km})\end{array}$ \\
\hline \multicolumn{7}{|l|}{ Resident females $(\mathrm{N}=2)$} \\
\hline with Class 1 cubs & 1.5 & 4.5 & 1.7 & 5.8 & 3.7 & 9.4 \\
\hline with Class 2 cubs & 1.6 & 8.5 & $2.8 *$ & 13.2 & $5.7 * *$ & 13.5 \\
\hline with Class 3 cubs & 2.2 & 9.4 & $3.7 * *$ & 11.3 & $7.8 * *$ & 15.6 \\
\hline without cubs & $4.8 * *$ & 10.8 & $5.4 * *$ & 12.3 & $7.6 * *$ & 15.0 \\
\hline Resident male $(\mathrm{N}=1)$ & 2.4 & 6.3 & $3.8^{*}$ & 13.9 & $11.8 * *$ & 22.9 \\
\hline Transients $(\mathrm{N}=2)$ & 2.3 & 7.5 & $4.1 * *$ & 17.5 & $8.7 * *$ & 19.5 \\
\hline Dispersing cubs $(N=6)$ & $3.2 *$ & 11.5 & $3.8 * *$ & 11.7 & $8.3 * *$ & 30.6 \\
\hline
\end{tabular}

*=probability mean distance moved greater than female with Class 1 cubs $<0.10$.

$* *=$ probability mean distance moved greater than female with Class 1 cubs $<0.05$. 
Appendix D). Annual home area size for resident females ranged from 396 to $1454 \mathrm{~km}^{2}$ and averaged $685 \mathrm{~km}^{2}$. Excluding the much larger area used by $\mathrm{F} 130$, the mean was $429 \mathrm{~km}^{2}$. The home area of the single resident male was $826 \mathrm{~km}^{2}$. Average seasonal range sizes for resident females were 236 and $347 \mathrm{~km}^{2}$ for winter and non-winter periods, respectively. For the resident male, these areas were 503 and $573 \mathrm{~km}^{2}$ in size. Activity radii showed no obvious seasonal trend, but seemed to reflect home area size (Table 4).

Transients used areas for varying periods, but established no lasting site attachment. Transient F50 used an area of $118 \mathrm{~km}^{2}$ for 5 months, then moved $45 \mathrm{~km}$ southwest where she remained for 6 months before being shot. F190, an orphaned cub, was released at 21 months of age. Acting presumably as a transient, she showed no site attachment for 8 months before apparently establishing residency $35 \mathrm{~km}$ northwest of the study area. Both F200 and F220 were about 2 years of age, and like F50, used relatively small areas. These two transients now share an area used by F210 before she died.

Resident cougars whose home areas included higher elevations (F80, F90, F150, M180) concentrated their activities in, but did not restrict them to higher elevations during the non-winter period (Figure 1, Table 4, Appendix E). Restriction to a relatively small, low-elevation area was common during the winter period, with depth of snow and prey availability possibly contributing to the determination of the actual time interval. A11 individuals, however, seemed to make these elevational movements simultaneously whenever the necessary conditions occurred. Mean elevations used during the non-winter period by residents F90, F150, and M180 were over $2700 \mathrm{~m}$ and significant1y greater 


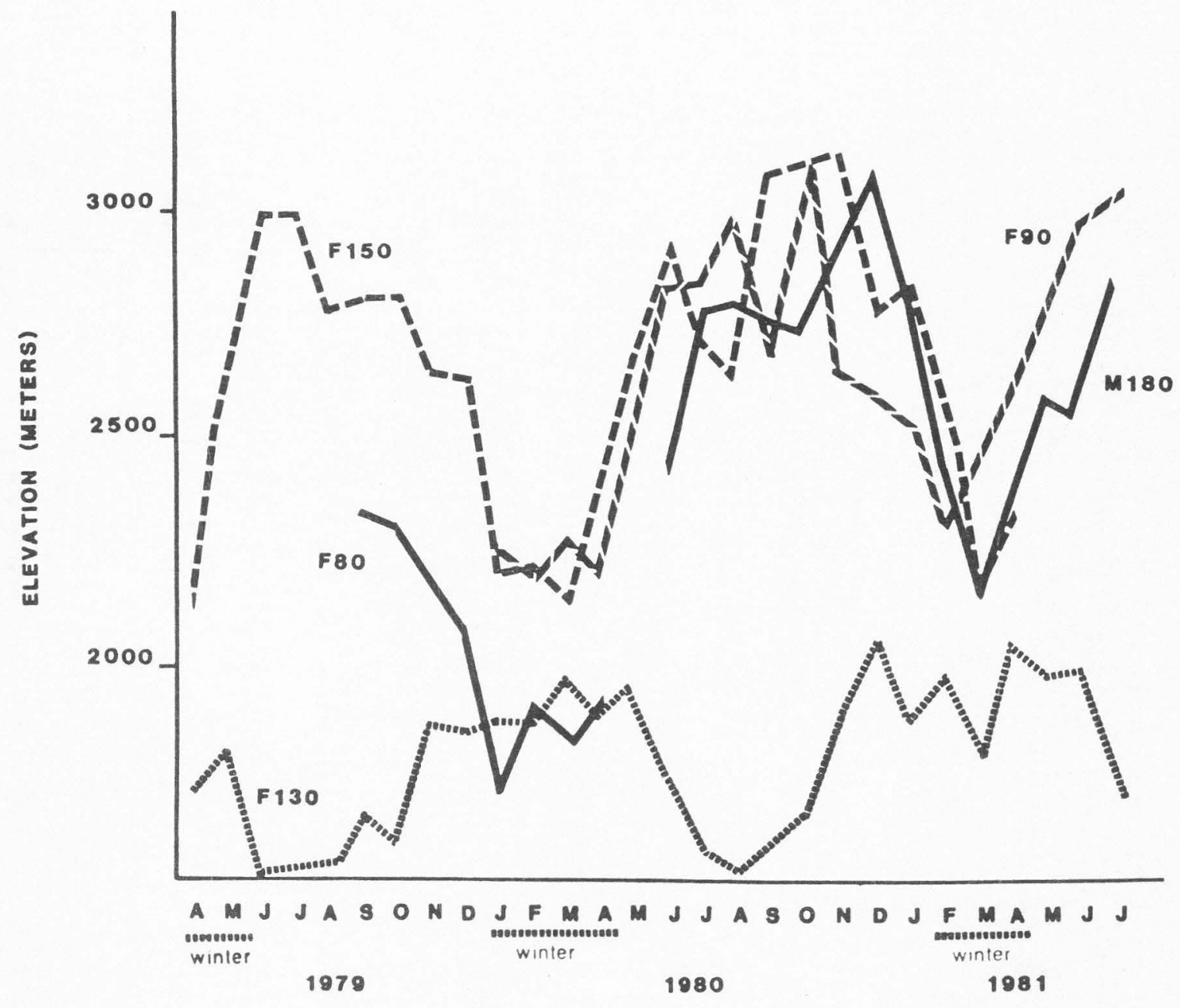

Figure I. Monthly mean elevations (m) for five resident cougars on the Boulder-Escalante study area, Utah, 1979-1981. 
$(p<0.016)$ than the mean elevations (2210 to $2429 \mathrm{~m})$ used during the winter periods. This pattern was also observed for F80, although the mean elevations were lower. Seasonal centers of activity also reflected this movement, with distances between winter and non-winter centers ranging from 5.3 to $16.2 \mathrm{~km}$ (Table 4, Appendix D).

Conversely, resident F130 used higher areas during winter $(\bar{x}=1921 \mathrm{~m})$ and lower elevations $\left(\bar{x}=1649 \mathrm{~m}, \mathrm{p}^{<0.001}\right)$ during the nonwinter. Her center of activities also reflected this elevational shift. The winter home areas of all resident cougars included portions of the mule deer and elk winter range (Table 4, Appendix D).

Linear distances moved during 1, 2, and 7-day intervals (Table 5) were variable but significant trends were found. Resident females with 0-6 month-old (Class 1) cubs (F90 and F150) moved significantly less $(p<0.05)$ than almost all other classes of cougars for 2 and 7-day intervals. Even in these other cases, however, there was a difference at $\mathrm{p}<0.10$. This trend was also apparent in the 1-day movement data, but samples were sma11 and only distances females without cubs moved differed significantly from distances traveled by females with Class 1 cubs. These trends became more pronounced as the time interval lengthened reflecting the refuging nature of a female with Class 1 cubs. One female (F150) returned to a den area for 5 to 6 weeks before moving her cubs. Resident females without cubs moved significantly farther in 1 day than a11 other classes of cougars $(p<0.05)$.

Maximum distance moved during these time intervals (Table 5) showed a similar trend with resident females with Class 1 cubs having the smallest value and those with older cub classes having progressively larger ones. The relatively large values recorded for all classes of 
cougars, however, demonstrated the potential mobility of this species, irrespective of age and reproductive status.

\section{Dispersion and intraspecific}

interactions

Although resident females $\mathrm{F} 150$ and F90 shared approximately 45 percent of their home areas (Figure 2), only four times were they observed within $1 \mathrm{~km}$ of each other. Resident female F130 shared areas with F150 and F90 but they were never observed in association. Additiona11y, tracks indicated that areas of use of resident female F70 and transient F50, as we11 as resident female F210 and transient/ resident female F220, overlapped each other. Transient female F190 was located in the home areas of several of the resident females. Resident M180 used portions of the home areas of at least five of six resident females (Figure 2).

Although only one male cougar was present during most of the study, we observed tracks which suggested that male home areas over1apped. When we began the study, sign suggested that at least two males were present, and that they were using substantially the same area. Although we were unable to confirm their status, both were large, and presumably adults.

Association of individual cougars, other than family groups, was recorded in on $1 y 33$, or 1.8 percent, of the radio relocations. Transient female F50 and dispersing female cub FC81 were observed in association once. Resident females F90 and F150 associated twice when they had Class 1 and Class 3 (12 months to dispersa1) cubs, respectively, and once when F90 had Class 2 (6 to 12 months-o1d) cubs and F150 had none. Six presumed mating associations were observed, including one 

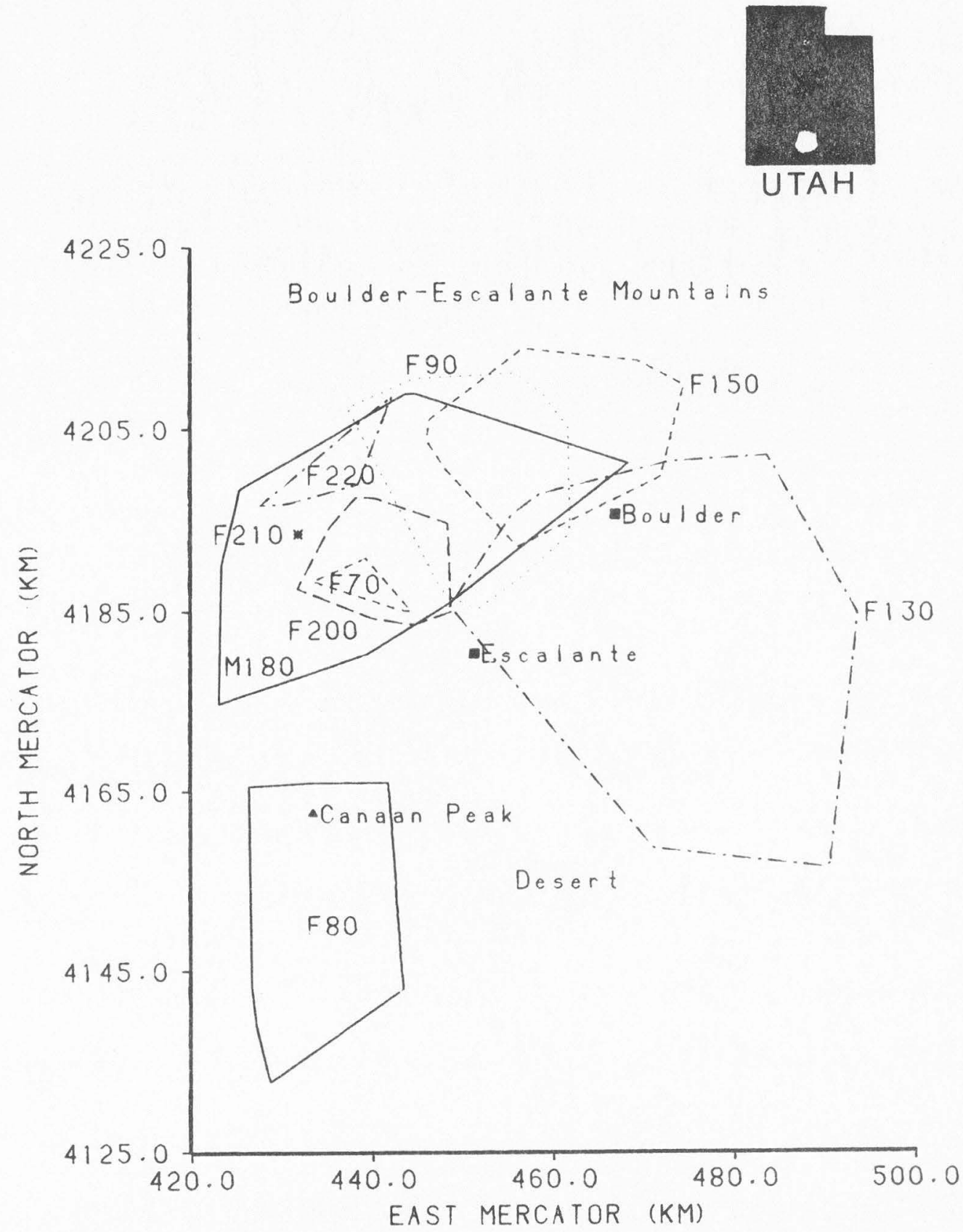

Figure 2. Home areas of resident cougars on the Boulder-Escalante study area, Utah, 1979-1981. 
where M180 and F220 shared an e1k ki11 for at least 3 days. An orphaned cub and an adult female, not her mother, also shared a deer kill for 3 days. Although resident males and resident females with cubs shared large areas they were not known to associate. Ten of 13 associations were documented by radio-tracking and three by identifiable tracks. Four associations determined by radio-tracking were investigated further and a11 were confirmed by tracks.

Although communication seems to be necessary to maintain the observed dispersion pattern, the means by which cougars communicate is not known. It likely, as suggested by Seidensticker et al. (1973), consists of both visual and olfactory cues. Male scratches were made under trees or rock outcroppings. Transects comparing frequency of scratches on ridgelines, creek edges and flat plateaus in spruceaspen vegetation indicated that about 30 times as many scratches were made on ridgelines as were made in the other areas (Appendix G), showing that scratches were located in predictable areas. Ninety-six percent of the scratches on ridgelines were made under dominant trees, although dominant trees made up only 11 percent of the trees present (Chi-square test, $\mathrm{p}<0.001$ ). Scats were found in 44 percent of the scratches $(\mathrm{N}=29)$. Three scratches contained evidence that they had been urinated in. Urine was probably not detectable by us for more than a few hours and the frequency of the behavior was probably greater than observed. Thirty-eight percent of all scratch sites $(\mathrm{N}=89)$ examined showed signs of previous use.

Twenty-two female scat mounds made by both transients and residents were found. These circular mounds of needles and soil were about $1 \mathrm{~m}$ 
across and $0.15 \mathrm{~m}$ high, and usually in the vicinity of a big game kill. Eighty-six percent of the mounds contained a scat. While Seidensticker et al. (1973) concluded that females buried scats to conceal them, 73 percent of the mounds we found were under dominant trees when dominant trees were present (i.e., not pinyon-juniper stands). This suggests these mounds, like scratches, were placed in conspicuous locations for detection and investigation rather than concealment. Female-cub associations were observed in detail throughout the study. Females often left their cubs while hunting and returned to move them to a new kill, with family members remaining closely associated for about a year. After this time the distance between members generally increased. The mean distance between F150 and her cubs was $0.10 \mathrm{~km}$ for Class $1,0.13 \mathrm{~km}$ for Class 2 , and $0.45 \mathrm{~km}$ for Class 3 cubs. Distances between $\mathrm{F} 90$ and her cubs were $0.70 \mathrm{~km}, 0.45 \mathrm{~km}$ and $1.36 \mathrm{~km}$, respectively, for the three cub classes. The mean distance between the mother and cubs in Classes 2 and 3 was different for F150 ( $p=0.09)$ and F90 ( $\mathrm{p}=0.08)$. The mean distance between F130 and her C1ass 2 cub was $1.75 \mathrm{~km}$. This distance was larger than those observed for F150 and F90 and their C1ass 2 cubs ( $p=0.002$ and $p=0.08$, respectively) and probably reflected the larger home area of F130.

Resident female F90 and F150 may have actually been farther from their Class 3 cubs than indicated. Increasingly during this period, one or more family members could not be located at any given time. Presumab1y, some members were relatively long distances from the rest of the family.

Although cubs are generally dependent on their mother for food until over a year of age, some cubs survived being orphaned at about 
6 months of age. One male cub, MC213, killed a deer at 9 months of age. Two of the three cubs in this 1itter, FC211 and FC212, however, died before 1 year of age. One was shot and the other died when it apparently fell and lodged in the fork of a tree.

Visual comparison of home areas of females with those of their cubs indicated that they were essentially identical (Appendix H). Minor differences observed in the home areas probably resulted from the method we used to delineate home areas. For this reason, we used FC81's movements as an indication of her uncollared mother's movements (Tables 1, 4). 


\section{DISCUSSION}

Although the purpose of scratches and scat mounds is unclear, the fact that they were placed in predictable areas suggests that they are used for intraspecific communication. Although Seidensticker et al. (1973) reported that virtually all scratches were made by resident males, we commonly observed male cubs to make scratches at less than a year of age. Dispersing male cubs also made scratches. These data suggest that territory demarcation may not be the primary purpose of scratches, but they may simply be a statement of temporal presence as observed for housecat urine-spraying by Leyhausen (1965).

Total population density and density of residents in the BoulderEscalante study area were less than 30 percent of those recorded in other areas. Home areas of resident females were from 3 to 30 times larger than reported elsewhere. The single male home area we observed was also larger than reported elsewhere for males. Care should be taken, however, when comparing study areas having different climatic conditions. The lack of seasonal deer migration on the California and Arizona study areas may have allowed cougars to use more localized areas on a year-round basis, which may account for the smaller home areas reported in these studies. Comparing the size of seasonal home areas in Utah to these year-round home areas may be more appropriate. A similar approach might also be justified in comparing population densities among areas. These comparisons, however, do not alter the conclusion that population density was lower and home area size markedly larger on our study area (Tables 3,6$)$. 
Table 6. Resident cougar home area sizes $\left(\mathrm{km}^{2}\right)$ and overlap characteristics reported in North America.

\begin{tabular}{|c|c|c|c|c|c|}
\hline Location & $\begin{array}{c}\text { Home area } \\
\text { type }\end{array}$ & $\begin{array}{c}\text { Male home }{ }^{\mathrm{a}} \\
\text { area sizes }^{2} \\
\overline{\mathrm{x}} \text { (range) } \mathrm{km}^{2}\end{array}$ & $\begin{array}{l}\text { Female home } \\
\text { area sizes } \\
\overline{\mathrm{x}} \text { (range) } \mathrm{km}^{2}\end{array}$ & $\begin{array}{l}\text { Within-sex } \\
\text { resident home } \\
\text { area overlap }\end{array}$ & Source \\
\hline Utah & $\begin{array}{r}\text { non-winter } \\
\text { winter } \\
\text { annual }\end{array}$ & $\begin{array}{l}573 \\
508 \\
826\end{array}$ & $\begin{array}{ll}347 & (232-556) \\
236 & (100-421) \\
685 & (396-1454)\end{array}$ & $\begin{array}{ll}\mathrm{F}, \mathrm{M} & ? \\
\mathrm{~F}, \mathrm{M} ? \\
\mathrm{~F}, \mathrm{M} ?\end{array}$ & This study \\
\hline Idaho & $\begin{array}{l}\text { summer } \\
\text { winter } \\
\text { annual }\end{array}$ & $\begin{array}{l}293 \\
126 \\
453\end{array}$ & $\begin{aligned} 148 & (106-207) \\
90 & (31-142) \\
268 & (173-373)\end{aligned}$ & $\begin{array}{l}F \\
F \\
F\end{array}$ & $\begin{array}{l}\text { Seidensticker et al. } \\
\text { (1973) }\end{array}$ \\
\hline California & year-round $\mathrm{d}^{\mathrm{b}}$ & 78 & $(39-45)$ & M & Sitton (1976) \\
\hline $\begin{array}{l}\text { British } \\
\text { Columbia }\end{array}$ & annual & 650 & $(13-52)$ & & Dewar and Dewar (1976) \\
\hline Arizona & year-round ${ }^{b}$ & $(123-162)$ & $(25-176)$ & $\mathrm{M}, \mathrm{F}$ & Shaw (1979) \\
\hline California & year-round ${ }^{b}$ & $(109-238)$ & $(57-74)$ & M & Kutilek et al. (1980) \\
\hline Nevada & annua1 & $616(534-816)$ & $161(117-244)$ & $\mathrm{M}, \mathrm{F}$ & Ashman (1981) \\
\hline
\end{tabular}

a Range presented when more than single value available.

${ }^{b}$ No distinct seasonal ranges. 
The total home area used by resident female F130 and the nonwinter area used by F80 were larger (Table 4) than those used by resident females $\mathrm{F} 90$ and $\mathrm{F} 150$, possibly because of variations in habitat quality. In addition, little overlap of movements was observed between either F130 and F80 and other cougars. Both of these females used areas that were rocky and vegetated by sparse pinyon-juniper woodlands and supported lower densities of prey than the areas used by F90 and F150. Seidensticker et a1. (1973) concluded that the area a resident cougar used, and the degree of overlap between females was a function of habitat quality as determined by a vegetation-topography/ prey numbers-vulnerability complex. The low numbers of deer and the relative lack of cover in which to stalk them may have required cougars F130 and F80 to cover larger areas to locate vulnerable prey. Non-hunting mortality appeared greater in southern Utah than in other areas. In 5 years of investigation, Hornocker (1970) observed only three natural mortalities. Currier et al. (1977) observed two in 3 years, Sitton (1977) found one in 2.5 years and Ashman (1976) saw only two in 3 years. We found eight dead cougars during the study suggesting that non-hunting mortality may be important in the dynamics of cougar populations. The degree to which hunting and natural deaths compensate for one another, however, is unknown. Four of the eight cougars had apparently been fed on by other cougars, but the cause of their death was unknown.

The cougar population on the study area was relatively stable for the three winters of the study. The number of resident females remained constant, with transient females compensating for losses of residents. The study area probably could have supported another 
resident male, but because no transient males were observed this hypothesis could not be tested. Dispersal of cubs appeared to be independent of adult resident density. Emigration of at least three dispersing male cubs through areas where no resident male cougars were present may support this conclusion, although minimum male breeding age is unknown.

Despite the difference in density, the social organization of the cougar population on the Boulder-Escalante study area appeared similar to the land-tenure system described in Idaho by Hornocker (1969, 1970) and Seidensticker et al. (1973). Resident and transient adult cougars were both present, but only residents bred. Transients established residency only when a resident cougar was removed. Overlap of home areas of resident females was common. Although we were unable to conclusively document similar trends among resident males, tracks and other sign suggested that home areas of resident males may also overlap. Although the pattern of intraspecific behavior we observed was similar to that described in Idaho, the influence of the social organization on dynamics of the cougar population was less clear. Seidensticker et al. (1973) concluded that social constraints maintained the breeding population below a level set by their food supply. On our study area deer and elk density was only about one-third that in northern Idaho, and below local levels of a decade ago. Although the magnitude of the numerical decline of the mule deer population is unknown, hunter success decreased from a mean of 67 percent during the 1966-1970 period to a mean of 30 percent during the 1975-79 period while the number of hunters afield remained relatively constant $(\bar{x}=999$ and $\bar{x}=1022$, respectively; Utah Division of Wildlife Resources 1972, 1981). 
Cougar numbers also declined during this. period. Annual sport harvests in the late 1960 s equaled or exceeded the total population now present. The presence of several old resident females in the present population suggests that overhunting was probably not the major cause of this decline.

The apparent simultaneous decline of the deer and cougar populations, while habitat remained intact, suggests that the cougar population responded to decreases in their major prey. We feel that mule deer numbers rather than social constraints were ultimately responsible for the decline of the cougar population in the years preceding the study. The social organization, however, probably dictated the mechanism of decline. Loss of residents by mortality or emigration may have been accelerated during this period. Presumably, voids created by this loss of residents were filled by expanded home areas of adjoining residents, and not by transients. This decrease in density of residents would probably have allowed continued reproduction by the remaining residents, certainly an advantage of this social pattern.

Sizes of both the deer population (Ackerman 1982) and the cougar population were relatively stationary in size during the period of this study. In addition, reproduction was near potential for the population, and transients compensated for losses of residents. We feel that the cougar population was regulated by social constraints on the density of breeding animals during the study although the limiting factor was deer numbers, probably the most limited of the resources to which the pattern of intraspecific behaviors responded. Other large predators have been observed to be limited by prey 
including coyotes (Todd et al. 1981), wolves (Fuller and Keith 1980, Nelson and Mech 1981), and Iynx (Brand and Keith 1979).

Presumably energetic constraints impose a limit on the size of cougar home areas. If deer density continued to decline in the area, reproduction and finally survival would be reduced. What social patterns would be operative under these conditions is unclear but a non-resident, highly unstable population would seem to be the final alternative. Conversely, if deer densities were to increase, cougar home area size and mortality would probably decrease. Associated with decreases in home area size would be an increase in overlap until a population not constrained by prey, as described by Hornocker (1969, 1970) and Seidensticker et al. (1973), was attained. Sensitivity of cougars to conditions that would result in relaxation of restraints on establishment of transients is unknown. However, even if restraints are lifted the rate at which the population will grow will be dependent on the availability of transients.

In conclusion, the social organization described by Seidensticker et a1. (1973) seemed functionally valuable even at the low prey densities we observed on our study area. We believe that a decrease in prey densities caused a decline in cougar numbers on this study area and the social organization simply dictated the mode of this decline. By limiting the establishment of transients even when residents were lost, requisites were presumably maintained at a level which allowed remaining residents to breed. 
MANAGEMENT IMPLICATIONS

The effects of hunting on cougar social patterns are unclear but disruption of a stable, resident-dominated population may allow an increase in the density of breeding animals. A subsequent increase in the number of dependent juveniles could cause an increase in the prey demands of the population. Smuts (1978) observed that cropping African lion populations increased the proportion of subadults and cubs in the population. Because these animals typically need more energy per body weight than adults, he concluded that this demographic change may compensate for any decrease in total lion biomass. Experimental removal of residents to test this hypothesis on cougar populations is a future objective of the present study.

The building of more roads on the study area and surrounding areas for logging and energy development will increase the hunting pressure on the cougar in these areas. Sport hunters generally drive roads in search of fresh tracks in the snow. This usually allows more efficient hunting than off-road methods. Our linear movement data suggest that resident female cougars with Class 1 cubs would become proportionally more vulnerable to hunting as the number of roads increases. With few roads, it is possible that a female with Class 1 cubs could localize in an area small enough that no roads would be encountered. Under these conditions, the chances of crossing a road would be higher for a female with cubs over 6 months of age, or single adu1ts, animals that move further than females with sma11, Class 1 cubs. This characteristic of localized movements becomes a detriment, however, 
as the number of roads increases, since the probability of all classes of cougars intersecting at least one road becomes high. Females with sma11 cubs not only move shorter distances, but for the first several weeks are in essence refuging predators, moving to and from a den. This increases the probability of crossing a road several times in a short period of time. The presence of several sets of tracks not only increases the probability that a hunter will initially detect the animal's presence, but also encourages him to monitor the area for new tracks if suitably fresh tracks are not observed the first time. A fall birth peak results in young cubs being present throughout the fall/winter hunting seasons common in Utah and most surrounding states. These cubs are particularly vulnerable to fatal maulings by dogs, and cub mortality should be expected even when females with cubs are not harvested. Additionally, although females with cubs are protected by $1 \mathrm{aw}$, it is often difficult to determine whether a female has cubs. Of six family groups we hunted for the first time, only the female was captured in four cases. Twice we were not aware that the female had cubs until later. We recorded females being as far as $14 \mathrm{~km}$ away from their Class 1 cubs for as 1 ong as 3 days. Consequently, 1aws protecting females with cubs may not totally meet their objective, because a hunter often has no way of being certain of the reproductive status of a female.

Dispersal of cubs irrespective of resident adult density also has important management implications. Essentia11y, populations may grow only from ingress. Immigration rates of transients into populations on isolated areas of habitat is probably slow. As hunting pressure increases around these areas, it will become even slower. For this 
reason, managers should recognize that these areas are particularly vulnerable to overexploitation (Ackerman et al. 1982). Conversely, if adequate sources of immigrants are available, hunting may stimulate the population and perhaps even result in increased cougar densities with resultant higher rates of predation on wild ungulates and perhaps livestock. Management strategies designed to provide huntable cougar populations on a sustained basis, while minimizing the impact of cougars on 1ivestock and wild ungulates, will need to carefully incorporate a complete understanding of the dynamics of cougar populations and the variables that drive them. 


\section{LITERATURE CITED}

Ackerman, B. B. 1982. Cougar predation and ecological energetics in south-central Utah. M.S. Thesis. Utah State Univ., Logan.

Ackerman, B. B., T. P. Hemker, F. G. Lindzey, and A. J. Button. 1982. Cougar numbers in the Henry Mountains, Utah. Encyclia (in press).

Ashman, D. 1976. In G. C. Christensen and R. J. Fischer, eds. Transactions of the mountain lion workshop. U.S. Fish and Wild1. Serv., Portland, Oregon. $213 \mathrm{pp}$.

Ashman, D. 1981. Mountain 1ion investigations. Nevada Dep. Fish and Game Rept., Proj. W-48-10, Job No. 5. 6 pp.

Brand, C. J., and L. B. Keith. 1979. Lynx demography during a snowshoe hare decline in Alberta. J. Wildl. Manage. 43:827-849.

Clark, W., D. A. Jessup, and A. Adams. 1979. Animal restraint handbook. Calif. Dep. Fish and Game. 113 pp.

Currier, M. J. P., S. L. Sheriff, and K. P. Russell. 1977. Mountain lion population and harvest near Canon City, Colorado, 1974-1977. Special Rept. No. 42, Colorado Div. Wildl. 11 pp.

Dewar, P. E., and P. C. Dewar. 1976. In G. C. Christensen and R. J. Fischer, eds. Transactions of the mountain lion workshop. U.S. Fish and Wildl. Serv., Portland, Oregon. 213 pp.

Dice, L. R., and P. J. Clark. 1953. The statistical concept of home range as applied to the recapture radius of the deer-mouse.

Contrib. Lab. Vert. Bio1., Univ. Michigan 62:1-15.

Fuller, T. K., and L. B. Keith. 1980. Wolf population dynamics and prey relationships in northeastern Alberta. J. Wildl. Manage. 44: 583-602.

Garcelon, D. K. 1977. An expandable drop-off transmitter collar for young mountain lions. Calif. Fish and Game 63:185-189.

Green, B. F. 1977. A practical interactive program for randomization tests. The American Statistician 31:37-39.

Hayne, D. W. 1949. Calculation of size of home range. J. Mamma1. 30: 1-18.

Hornocker, M. G. 1969. Winter territoriality in mountain lions. J. Wild1. Manage. 33:457-464. 
Hornocker, M. G. 1970. An analysis of mountain lion predation upon mule deer and elk in the Idaho Primitive Area. Wild1. Monogr. 21. $39 \mathrm{pp}$.

Koford, C. B. 1978. The welfare of the puma in California. Carnivore $1: 92-96$.

Kutilek, M. J., R. A. Hopkins, and T. E. Smith. 1980. Second annua1 report on the ecology of mountain lions in the Diablo Range of California. Dep. Bio. Sci., Calif. State Univ., San Jose. 21 pp.

Leyhausen, P. 1965. The communal organization of solitary mammals. Symp. Zoo1. Soc. London 14:249-263.

Nelson, M. E., and L. D. Mech. 1981. Deer social organization and wolf predation in northeastern Minnesota. Wildl. Monogr. 77.53 pp.

Robinette, W. L., J. S. Gashwiler, and D. W. Morris. 1961. Notes on cougar productivity and life history. J. Mammal. 42:204-217.

Seidensticker, J. C., M. G. Hornocker, W. V. Wiles, and J. P. Messick. 1973. Mountain lion social organization in the Idaho Primitive Area. Wild1. Monogr. 35. $60 \mathrm{pp}$.

Shaw, H. G. 1977. Impact of mountain lions on mule deer and cattle. Pages 17-32 in R. L. Phillips and C. J. Jonkel, eds. Proc. 1975 Predator Symp., Montana For. and Cons. Exp. Sta., School of Forestry, Univ. Montana, Missoula. 268 pp.

Shaw, H. G. 1979. A mountain 1ion field guide. Ariz. Game and Fish Dep. Spec. Rept. 9. Phoenix. 27 pp.

Shaw, H. G. 1980. Ecology of the mountain 1ion in Arizona. Ariz. Game and Fish Dep. Rept. Proj. W-78-R, Job 13. 14 pp.

Sitton, L. W. 1976. In G. C. Christensen and R. J. Fischer, eds. Transactions of the mountain lion workshop. U.S. Fish and Wild1. Serv., Portland, Oregon. 213 pp.

Sitton, L. W. 1977. California mountain lion investigations with recommendations for management. Calif. Dep. Fish and Game. $35 \mathrm{pp}$.

Smuts, G. L. 1978. Effects of population reduction on the travels and reproduction of lions in Kruger National Park. Carnivore 1: 61-72.

Todd, A. W., L. B. Keith, and C. A. Fischer. 1981. Population ecology of coyotes during a fluctuation of snowshoe hares.

U.S. Department of Commerce. 1979. Climatological data annual summary. Climatologica1 Data--Utah 81(13). 
Utah Division of Wildlife Resources. 1972. Utah big game investigations and management recommendation book. Pub1. 72-6.

Utah Division of Wildlife Resources. 1980. The Utah cougar harvest book. Pub1. 80-17. 16 pp.

Utah Division of Wildlife Resources. 1981. Utah big game investigations and management recommendations book. Pub1. 81-4. 
APPENDICES 
Appendix A

Time Intervals During Which Cougars Were Tracked

by Radio-telemetry

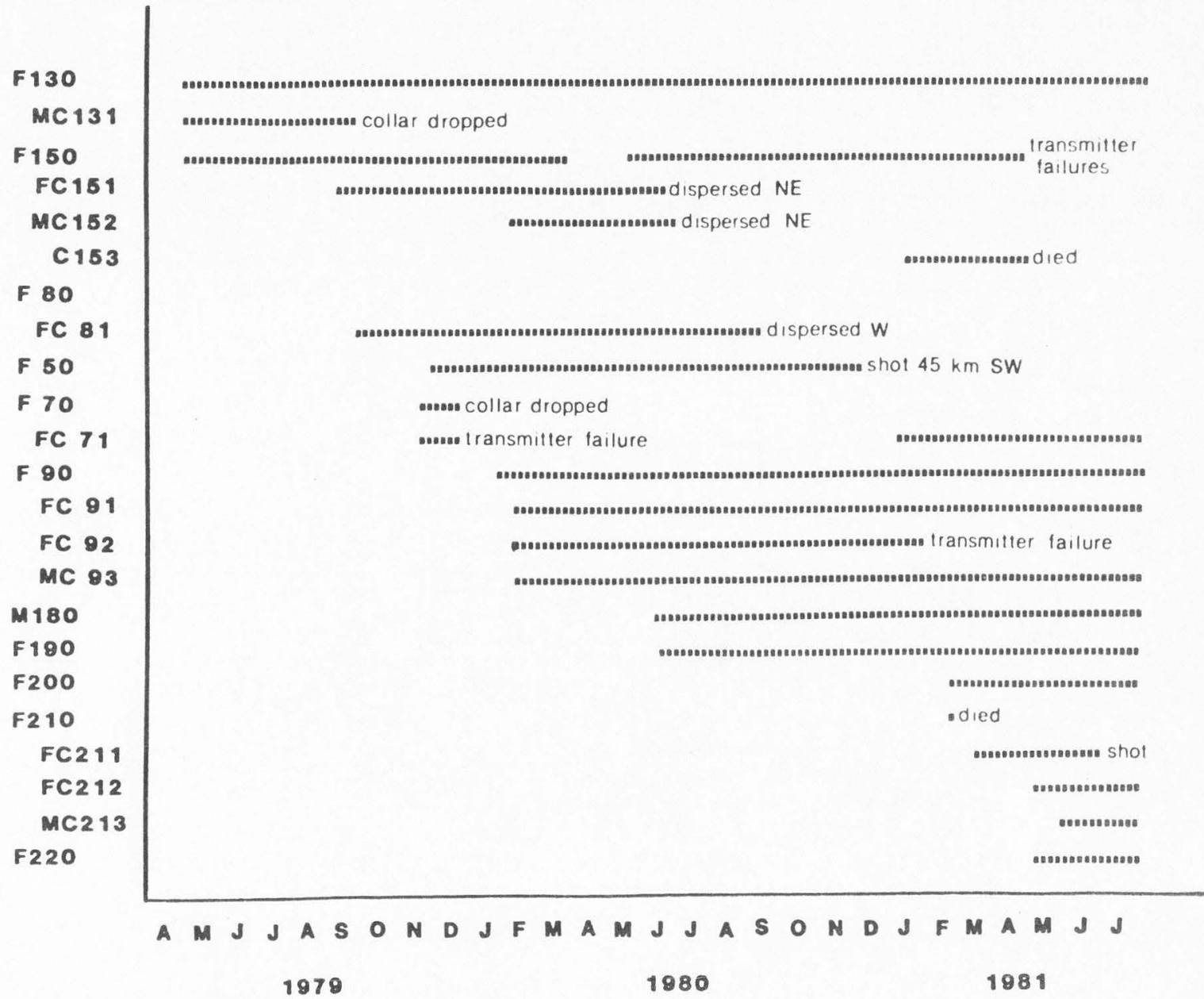

Figure 3. Time intervals 22 cougars were tracked using radio-telemetry on the Boulder-Escalante study, Utah, 1979-1981. 
Table 7. Physical measurements made of 22 cougars at capture on the Boulder-Escalante study area, Utah, 1979-1981.

\begin{tabular}{|c|c|c|c|c|c|c|c|c|c|c|c|c|c|c|c|c|c|c|}
\hline Cougar & $\begin{array}{l}\text { Capture } \\
\text { Date }\end{array}$ & $\begin{array}{c}\text { We1ght } \\
(\mathrm{kg})\end{array}$ & Age & & $\begin{array}{l}\text { Foot pad } \\
\text { R Front }\end{array}$ & $\begin{array}{l}\text { size (le } \\
\text { L Front }\end{array}$ & $\begin{array}{l}\text { ngth/wid } \\
\text { R Rear }\end{array}$ & $\begin{array}{c}\text { th } \mathrm{mm} \text { ) } \\
\text { L Rear }\end{array}$ & $\begin{array}{l}\text { Can1ne } \\
\text { R Upper }\end{array}$ & $\begin{array}{l}\text { teeth (len } \\
\text { L Upper }\end{array}$ & $\begin{array}{l}\text { gth/width } \\
\text { R Lower }\end{array}$ & $\begin{array}{l}\text { (um) } \\
\mathrm{L} \text { Lower }\end{array}$ & $\begin{array}{l}\text { Total } \\
\text { length } \\
(\mathrm{cm})\end{array}$ & $\begin{array}{l}\text { Ta11 } \\
(\mathrm{cm})\end{array}$ & $\begin{array}{l}\text { Neck } \\
(\mathrm{cm})\end{array}$ & $\begin{array}{l}\text { Hock } \\
(\mathrm{cm})\end{array}$ & $\begin{array}{l}\text { Shoulder } \\
(\mathrm{cm})\end{array}$ & $\begin{array}{l}\text { Chest } \\
(\mathrm{cm})\end{array}$ \\
\hline F 130 & $4 / 21 / 79$ & 46 & $7-9$ y & & $49 / 56$ & $45 / 56$ & $46 / 51$ & $44 / 49$ & $21 / 12$ & $21 / 12$ & $19 / 12$ & $19 / 12$ & 193 & & & & & \\
\hline MC131 & $4 / 22 / 79$ & 26 & $1978 \mathrm{c}$ & cub & $39 / 51$ & $38 / 50$ & $35 / 42$ & $34 / 43$ & $9 / 6$ & $9 / 6$ & 716 & $6 / 6$ & 161 & 61 & 29 & 25 & & \\
\hline F 150 & $4 / 24 / 79$ & 52 & $5-6$ y & yr & $45 / 57$ & $43 / 57$ & $42 / 48$ & $41 / 48$ & $28 / 13$ & $18 / 13$ & $23 / 13$ & $23 / 13$ & 206 & 75 & 29 & 28 & 61 & 70 \\
\hline FC151 & $9 / 7 / 79$ & 36 & $1978 \mathrm{c}$ & cub & $44 / 53$ & $47 / 55$ & $40 / 47$ & $42 / 49$ & $24 / 12$ & $25 / 12$ & $20 / 11$ & $20 / 11$ & & & 31 & 28 & & \\
\hline FC 81 & $9 / 28 / 79$ & 32 & $1978 \mathrm{c}$ & cub & $40 / 52$ & $42 / 48$ & $38 / 43$ & $40 / 43$ & $24 / 12$ & $24 / 11$ & $20 / 11$ & $19 / 11$ & 189 & 71 & 32 & 27 & & \\
\hline F 50 & $12 / 6 / 79$ & 37 & $2 y$ & $\mathrm{yr}$ & $41 / 52$ & $40 / 52$ & $39 / 45$ & $39 / 45$ & $22 / 11$ & $23 / 11$ & $19 / 10$ & $19 / 10$ & 175 & 69 & 31 & 26 & 56 & 60 \\
\hline F 130 & $1 / 12 / 80$ & 46 & $7-9 y$ & yr & $44 / 52$ & $48 / 53$ & $44 / 49$ & $43 / 48$ & $20 / 10$ & $21 / 10$ & $18 / 12$ & $18 / 12$ & 193 & 78 & 34 & 27 & & \\
\hline FC 71 & $1 / 14 / 80$ & 18 & 1979 & cub & $36 / 45$ & $36 / 45$ & $35 / 41$ & $35 / 41$ & $10 / 6$ & $11 / 7$ & $10 / 7$ & $10 / 8$ & 143 & 54 & & 22 & & \\
\hline P 70 & $1 / 14 / 80$ & 45 & $3-49$ & yr & $40 / 50$ & $43 / 51$ & $40 / 42$ & $40 / 43$ & $25 / 12$ & $25 / 12$ & $20 / 12$ & $20 / 12$ & 187 & 67 & 35 & 25 & 67 & 62 \\
\hline F 90 & $2 / 15 / 80$ & 46 & $3-4 y$ & $\mathrm{yr}$ & $42 / 52$ & $42 / 51$ & $37 / 41$ & $36 / 45$ & 271 & $21 / 12$ & 271 & $22 / 11$ & 195 & 69 & 33 & 27 & & 64 \\
\hline FC 92 & $2 / 15 / 80$ & 22 & 1979 & cub & $33 / 45$ & $33 / 45$ & $35 / 39$ & $35 / 39$ & $11 / 7$ & $11 / 7$ & $9 / 7$ & $9 / 7$ & 141 & 57 & 27 & 23 & 48 & 56 \\
\hline MC 93 & $2 / 16 / 80$ & 24 & 1979 & cub & $38 / 49$ & $38 / 50$ & $35 / 43$ & $34 / 44$ & $12 / 7$ & $13 / 7$ & $11 / 7$ & $10 / 7$ & 150 & 57 & 28 & 24 & 50 & 53 \\
\hline FC 91 & $2 / 17 / 80$ & 24 & 1979 & cub & $37 / 47$ & $38 / 46$ & $34 / 41$ & $33 / 42$ & $10 / 7$ & $10 / 6$ & $8 / 7$ & $9 / 7$ & 149 & 59 & 27 & 24 & 54 & 49 \\
\hline MC 152 & $2 / 5 / 80$ & 52 & 1978 & cub & $49 / 61$ & $49 / 59$ & $42 / 55$ & $42 / 55$ & $27 / 13$ & $26 / 13$ & $22 / 13$ & $24 / 14$ & 209 & 82 & 38 & 29 & & 65 \\
\hline F $\quad 50$ & $4 / 20 / 80$ & 39 & $2 y$ & $\mathrm{yr}$ & & & & & $21 / 11$ & $21 / 11$ & $19 / 11$ & $18 / 10$ & 198 & 77 & 33 & & 57 & 64 \\
\hline F 150 & $5 / 11 / 80$ & 51 & $5-6$ y & yr & $44 / 53$ & $44 / 55$ & $41 / 49$ & $41 / 45$ & $28 / 15$ & $18 / 13$ & $29 / 18$ & $29 / 18$ & 208 & 74 & 36 & & & 70 \\
\hline FC 91 & $5 / 20 / 80$ & 23 & 1979 & cub & & & & & $20 / 11$ & $21 / 11$ & $18 / 11$ & $18 / 10$ & 160 & 61 & 28 & & 54 & 54 \\
\hline FC 92 & $5 / 20 / 80$ & 22 & 1979 & cub & $37 / 46$ & $38 / 44$ & $37 / 40$ & $35 / 40$ & $22 / 11$ & $22 / 12$ & $18 / 10$ & $17 / 11$ & 163 & 60 & 27 & & 51 & 49 \\
\hline M 180 & $6 / 4 / 80$ & 59 & $3-4$ & yr & $51 / 60$ & $47 / 63$ & $48 / 52$ & $50 / 51$ & $30 / 15$ & $30 / 15$ & $25 / 14$ & $25 / 15$ & 221 & 78 & 39 & 30 & 68 & 81 \\
\hline $\mathrm{C} 153$ & 2/ $8 / 81$ & 9 & 1980 & cub & & & $22 / 34$ & 132 & & & & & 107 & & & & & \\
\hline FC 71 & $2 / 12 / 81$ & 43 & 1979 & cub & $41 / 54$ & & $38 / 47$ & & & & & & 193 & & & & & \\
\hline$F 200$ & $2 / 27 / 81$ & 31 & 25 & $\mathrm{yr}$ & $33 / 48$ & & & $31 / 40$ & & & & & 178 & & & & & \\
\hline F 210 & $3 / 6 / 81$ & 38 & $7-93$ & yr & & & & & & & & & 201 & & & & & \\
\hline FC211 & $3 / 20 / 81$ & est21 & 1980 & cub & & & & & & & & & 152 & & & & & \\
\hline FC212 & $5 / 2 / 81$ & 24 & 1980 & cub & & & & & & & & & 172 & & & & & \\
\hline P 220 & $5 / 4 / 81$ & 36 & 25 & yr & & & & & & & & & 192 & & & & & \\
\hline $\mathrm{FC} 213$ & $5 / 28 / 81$ & 30 & 1980 & cub & & $67 / 52$ & & $72 / 44$ & $21 / 11$ & $22 / 10$ & & $21 / 12$ & 176 & 65 & 29 & & & 86 \\
\hline
\end{tabular}

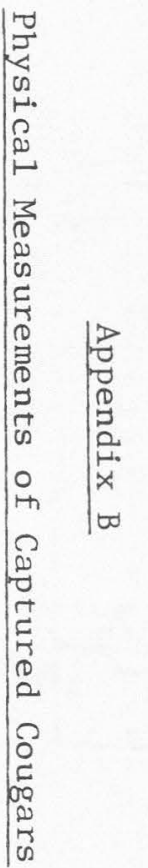




\section{Appendix C \\ Initial Distance Moved by Captured Cougars}

With few exceptions, we were aware of a cougar's presence before it was captured. In no instances did captured animals subsequently leave the area where we had previously observed them to use before capture. Cougars showed a tendency to move shorter distances after capture, presumably while recovering from minor injuries suffered at capture (Table 8). Movements of a cougar recorded 1 day after it was treed, 3 days after it was captured and handled, and 2 weeks after capture and toe removal were omitted from the linear movement analyses presented in the Results.

Table 8. One-day movement patterns of cougars after capture compared to non-capture movement patterns on the Boulder-Escalante study area, Utah, 1979-1981.

\begin{tabular}{lccc}
\hline $\begin{array}{c}\text { Cougar } \\
\text { class }\end{array}$ & $\begin{array}{c}\overline{\mathrm{x}} \text { distance } \\
\text { moved after } \\
\text { capture }(\mathrm{km})\end{array}$ & $\begin{array}{c}\overline{\mathrm{x}} \text { non-capture } \\
\text { distance } \\
\text { moved }(\mathrm{km})\end{array}$ & $\begin{array}{c}\text { Difference } \\
\text { from } \\
\text { normal }(\mathrm{km})\end{array}$ \\
\hline $\begin{array}{l}\text { Resident female } \mathrm{a} \\
\text { Resident male }\end{array}$ & $0.9(\mathrm{~N}=14)$ & 1.7 & -0.8 \\
Transients & $3.9(\mathrm{~N}=1)$ & 2.4 & +1.5 \\
\hline
\end{tabular}

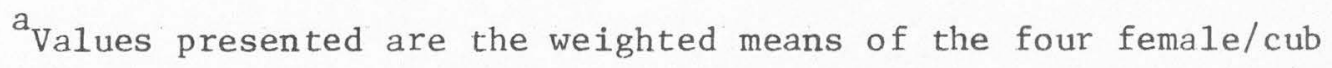
classes. 


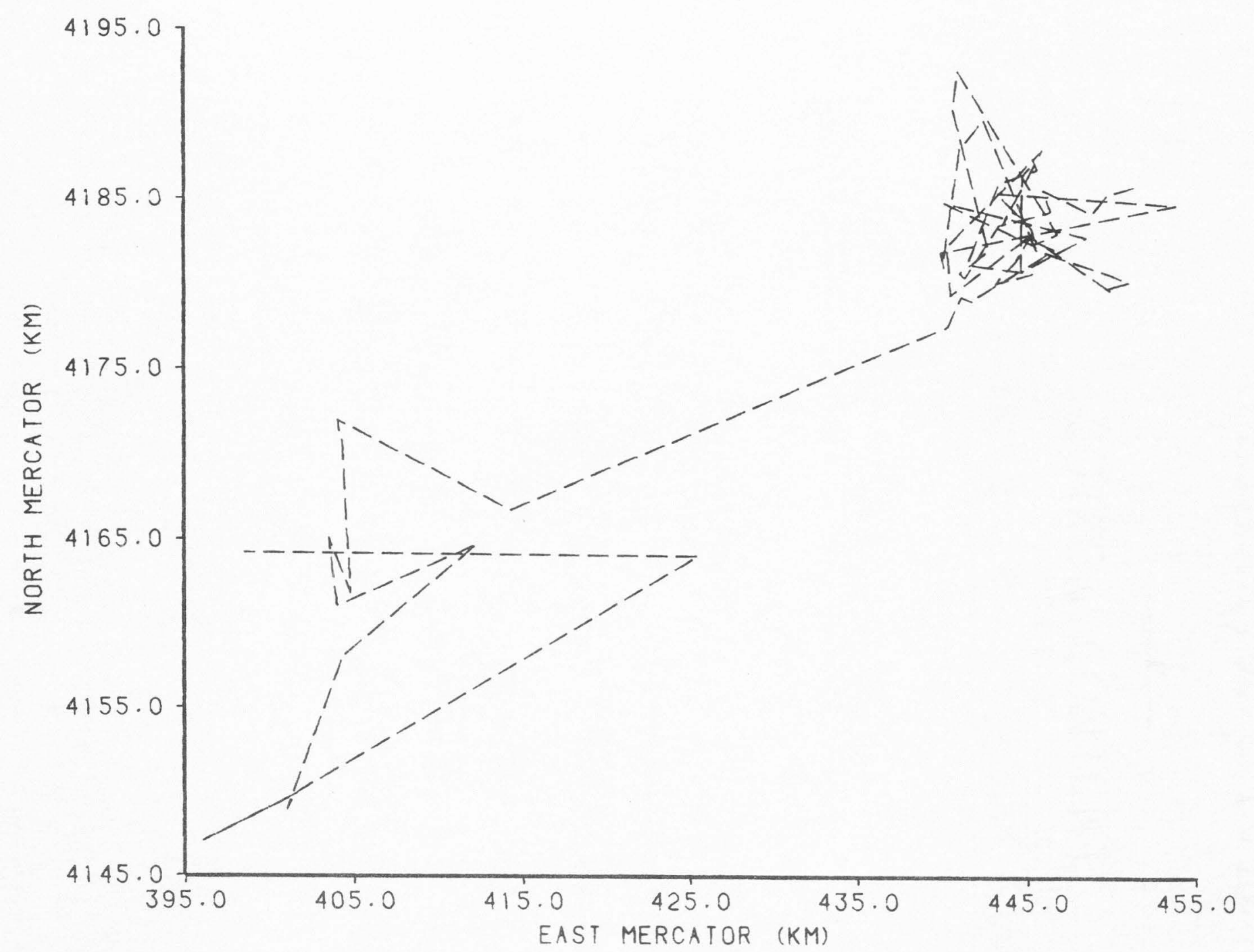

Figure 4. Lines connecting capture and relocation sites of transient female cougar F50 on the Boulder-Escalante study area, Utah, from 6 December 1979 to 28 November 1980 . 


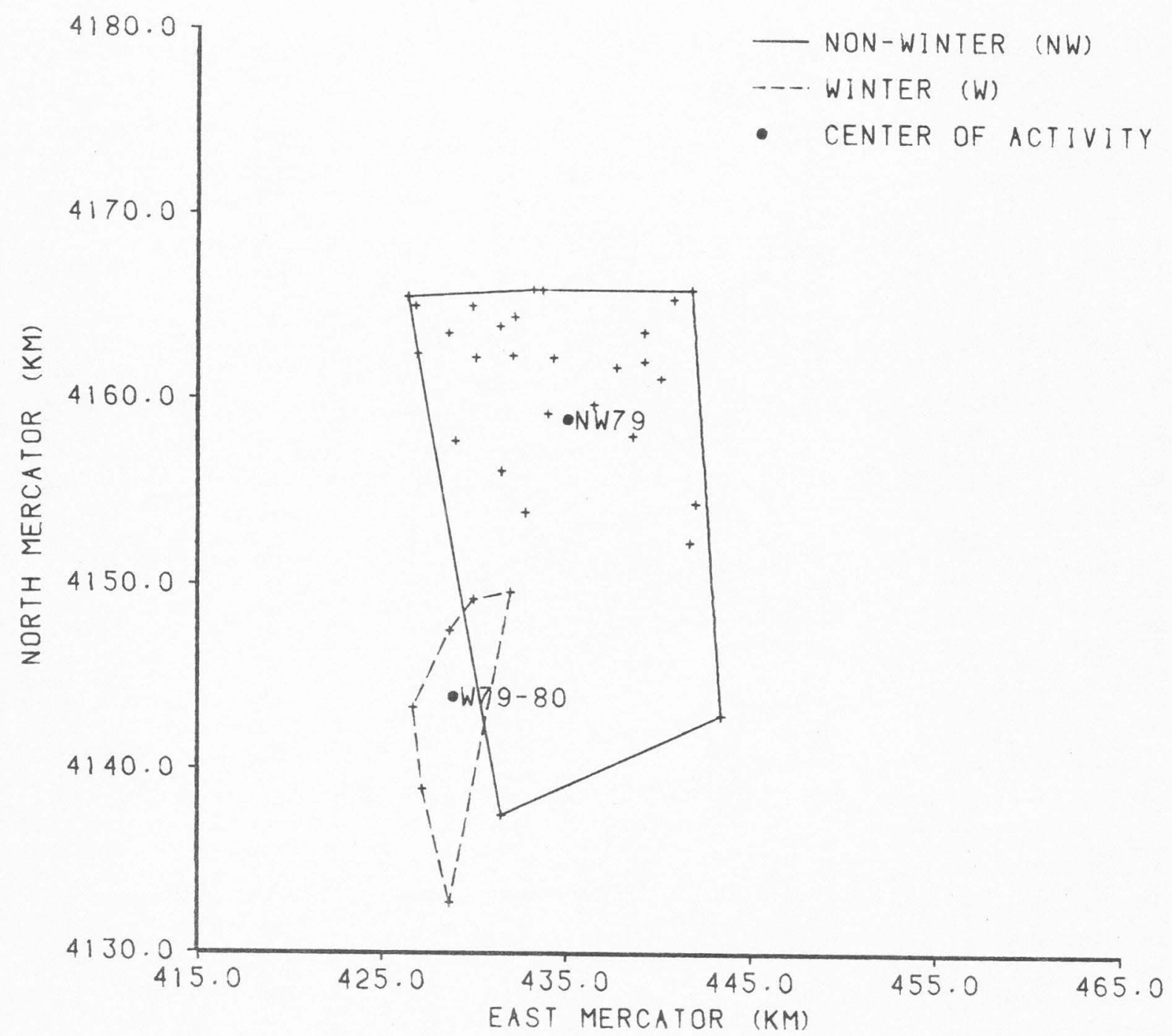

Figure 5. Capture and relocation sites, seasonal home areas, and seasonal centers of activity for resident female cougar F80 on the Boulder-Escalante study area, Utah, from 28 October 1979 to 19 April 1980. 


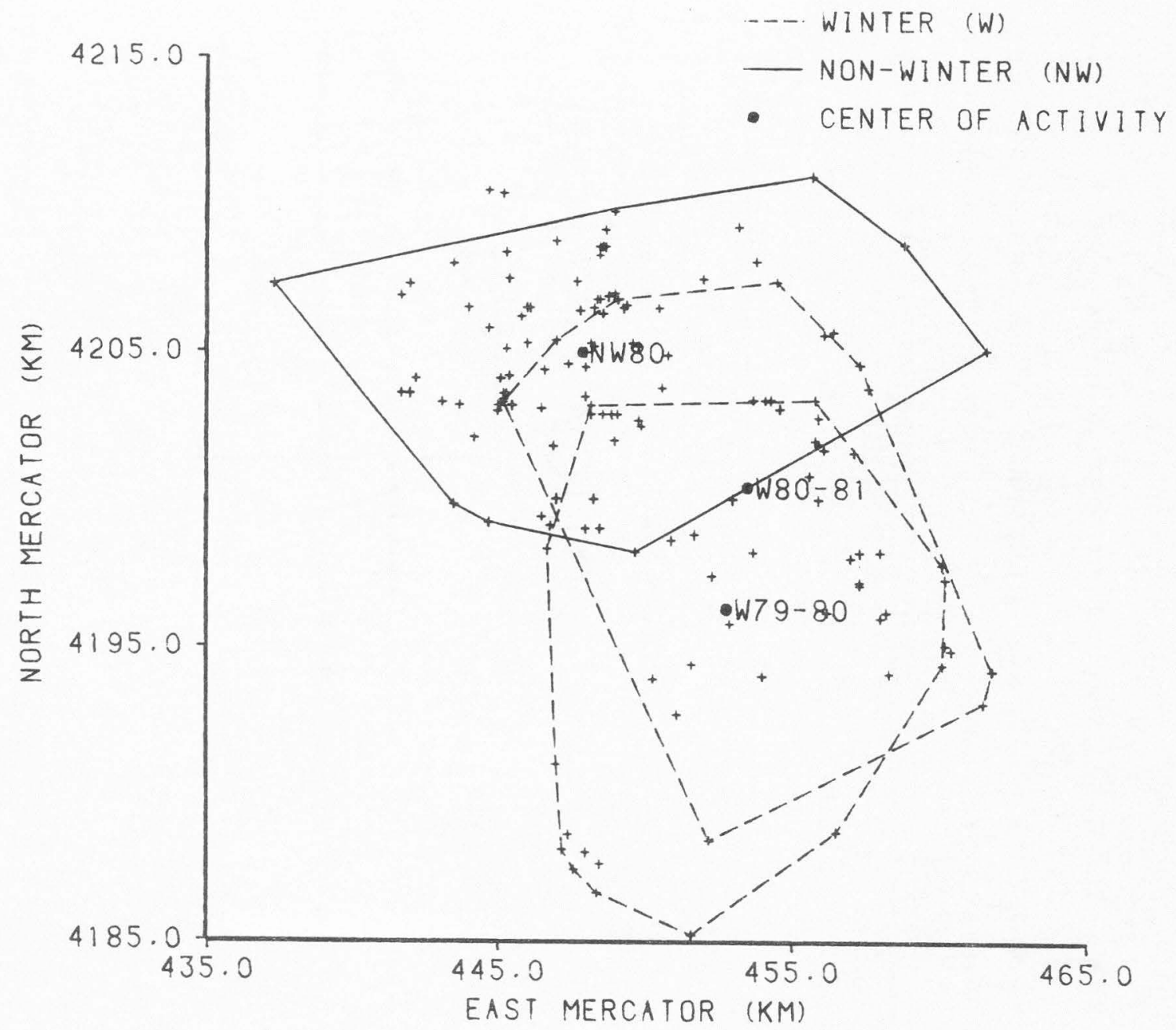

Figure 6. Capture and relocation sites, seasonal home areas, and seasonal centers of activity for resident female cougar F90 on the Boulder-Escalante study area, Utah, from 24 January 1980 to $30 \mathrm{July} 1981$. 


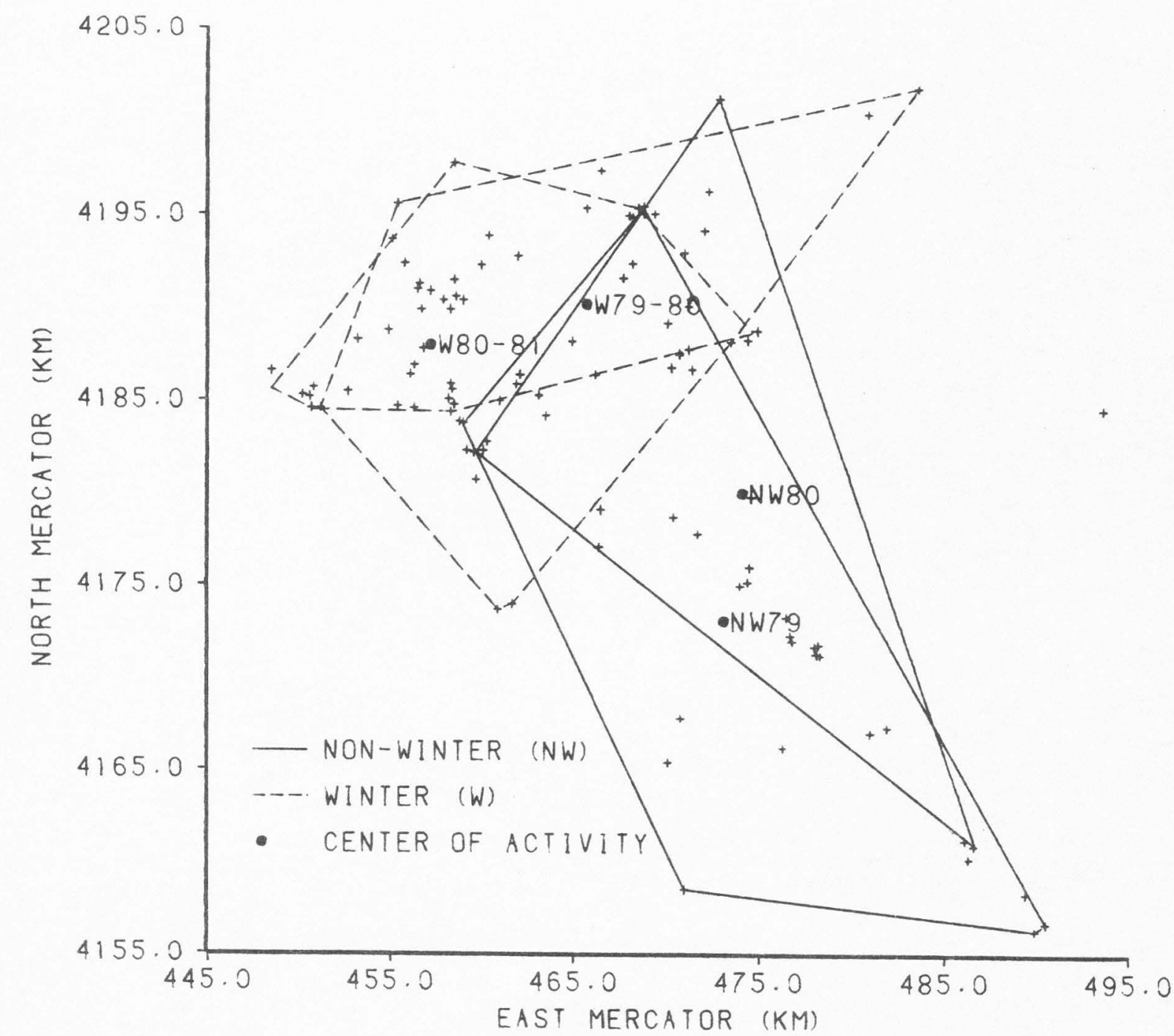

Figure 7. Capture and relocation sites, seasonal home areas, and seasonal centers of activity for resident female cougar F130 on the Boulder-Escalante study area, Utah, from 21 April 1979 to $17 \mathrm{July} 1981$. 


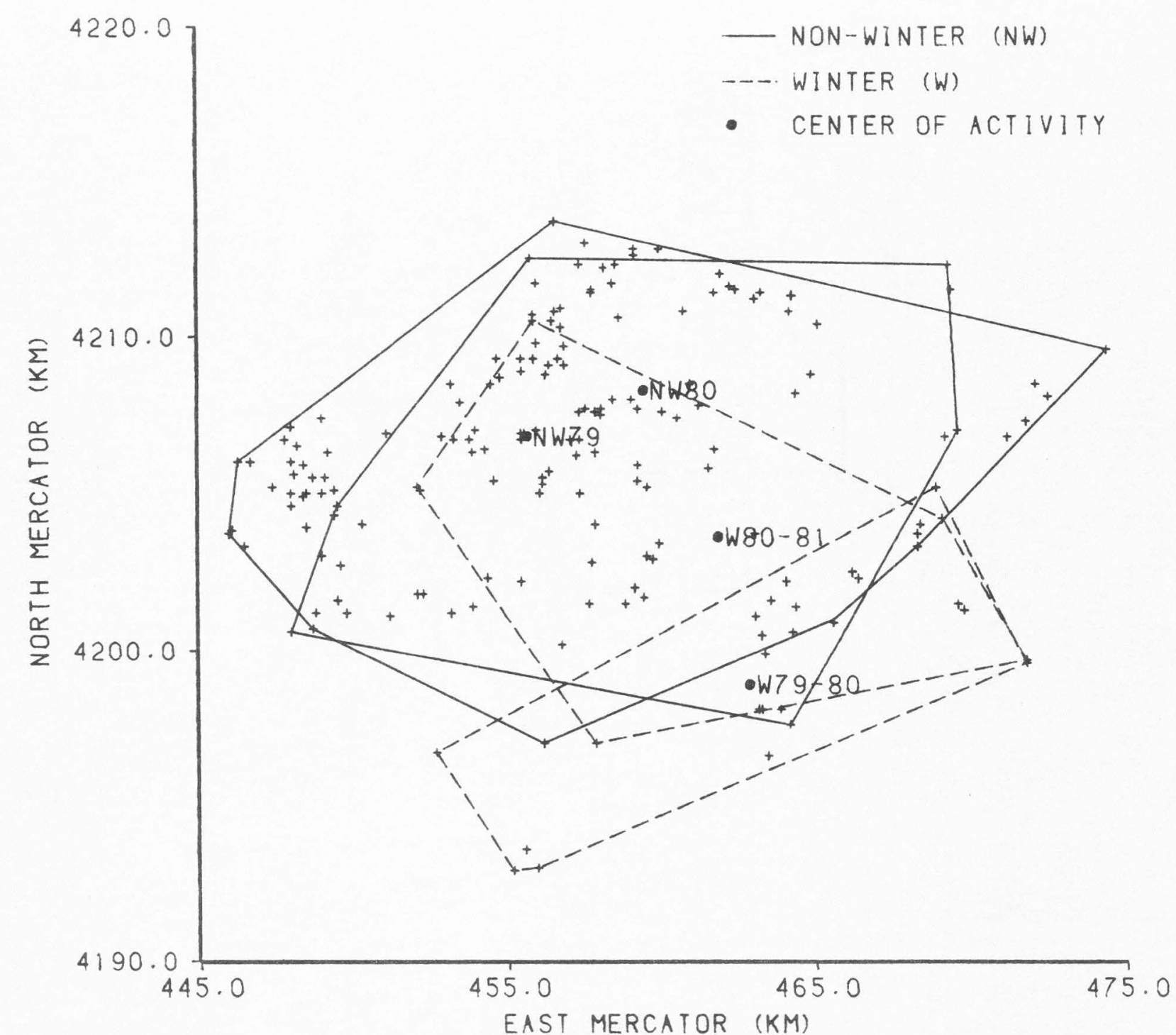

Figure 8. Capture and relocation sites, seasonal home areas, and seasonal centers of activity for resident female cougar F150 on the Boulder-Escalante study area, Utah, from 24 April 1979 to 14 April 1981. 


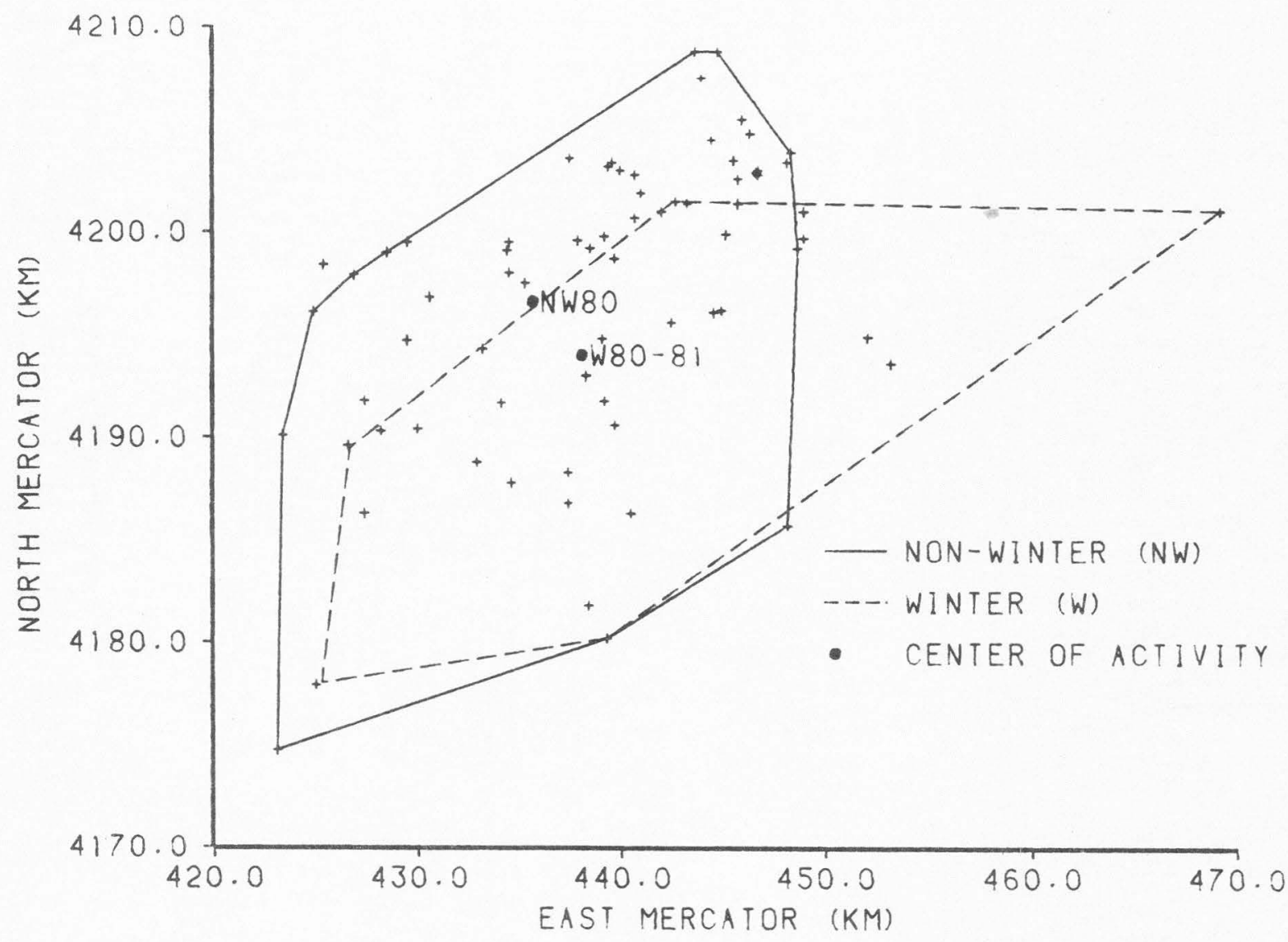

Figure 9. Capture and relocation sites, seasonal home areas, and seasonal centers of activity for resident male cougar M180 on the Boulder-Escalante study area, Utah, from 4 June 1980 to 28 July 1981. 


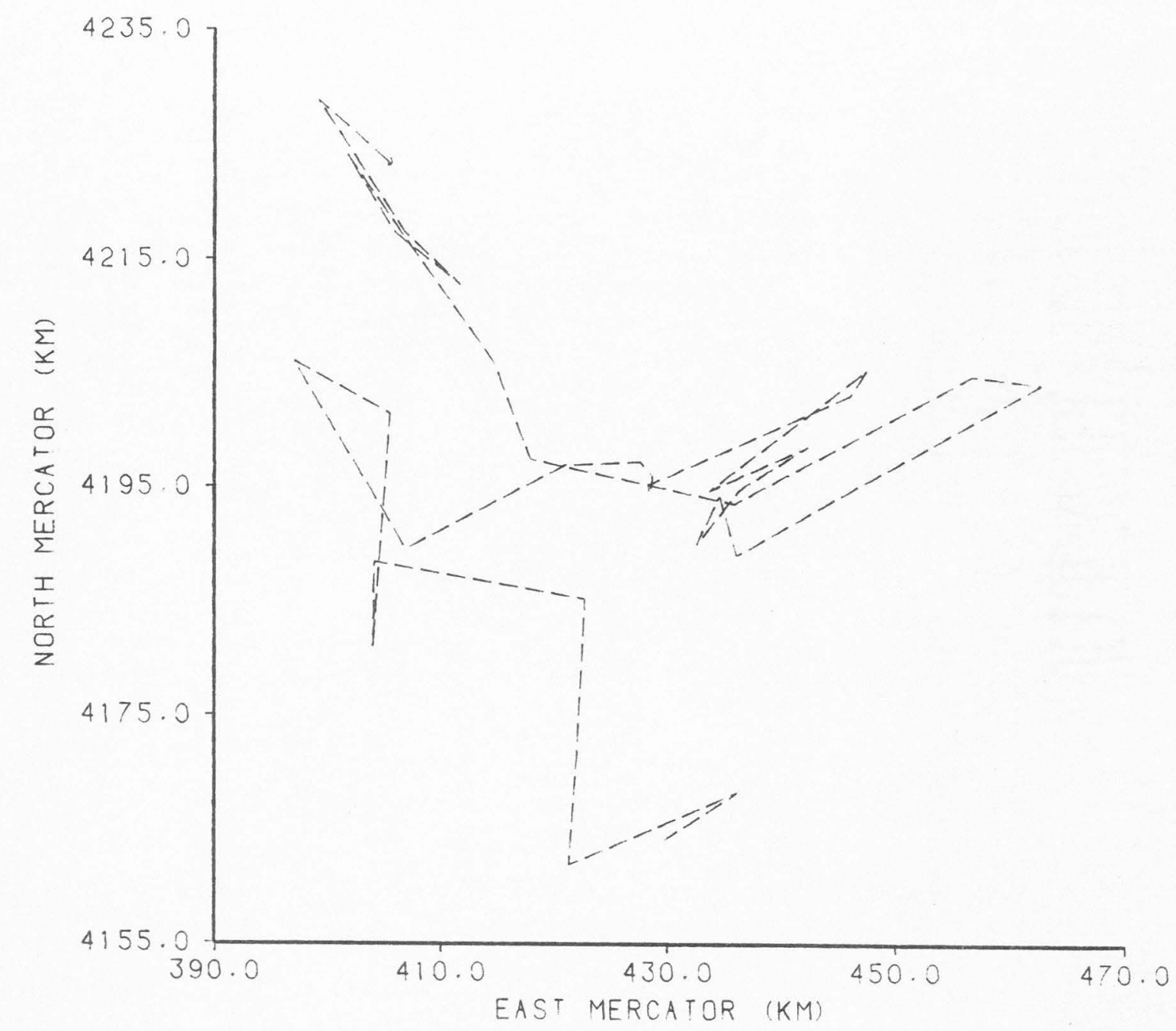

Figure 10. Lines connecting capture and relocation sites of transient female cougar F190 on the Boulder-Escalante study area, Utah, from 17 June 1980 to 30 July 1981. 


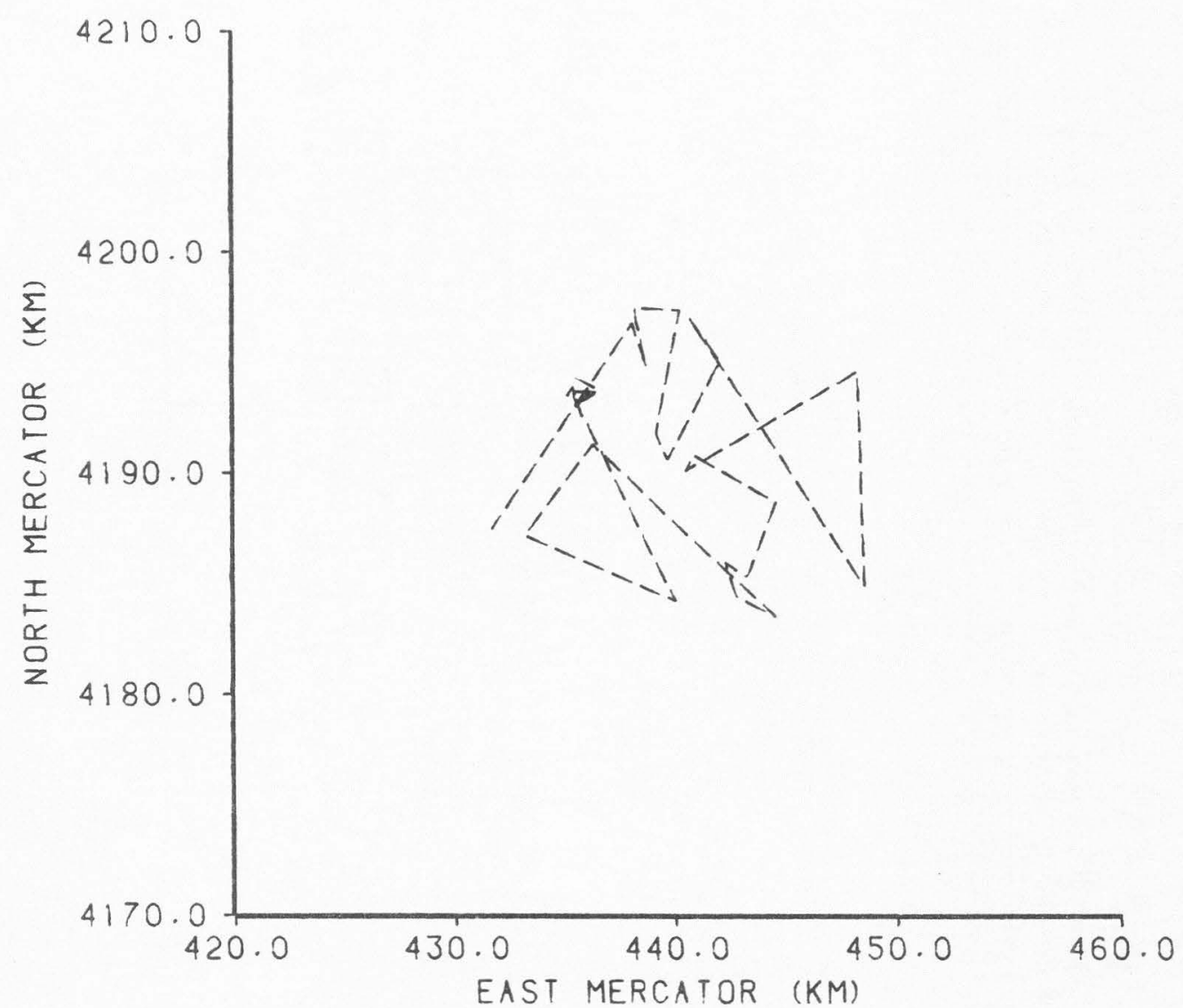

Figure 11. Lines connecting capture and relocation sites of transient/resident female cougar F200 on the Boulder-Escalante study area, Utah, from 27 February 1981 to $30 \mathrm{July} 1981$. 


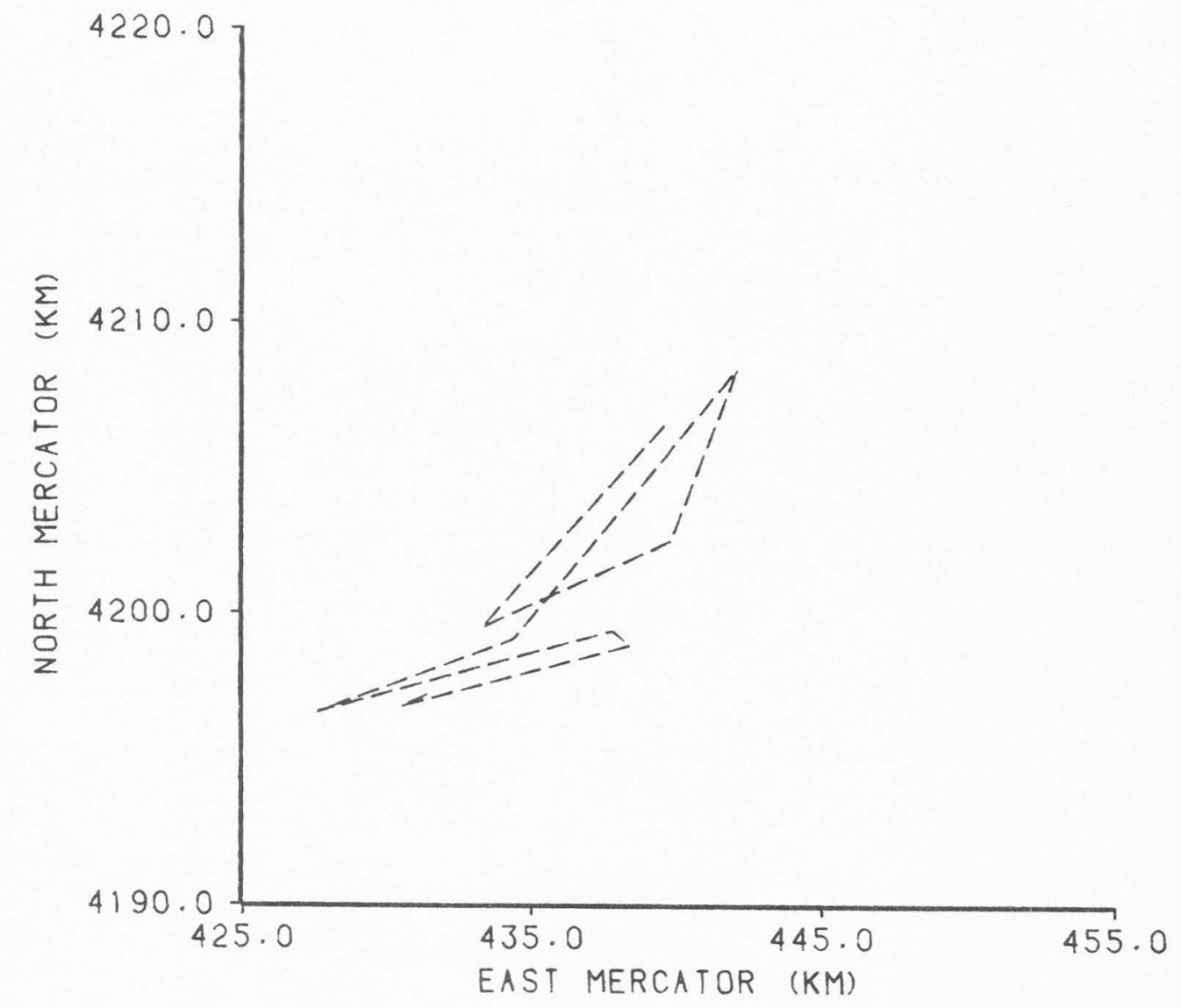

Figure 12. Lines connecting capture and relocation sites of transient/resident female cougar F220 on the Boulder-Escalante study area, Utah, from 4 May 1981 to 30 July 1981. 

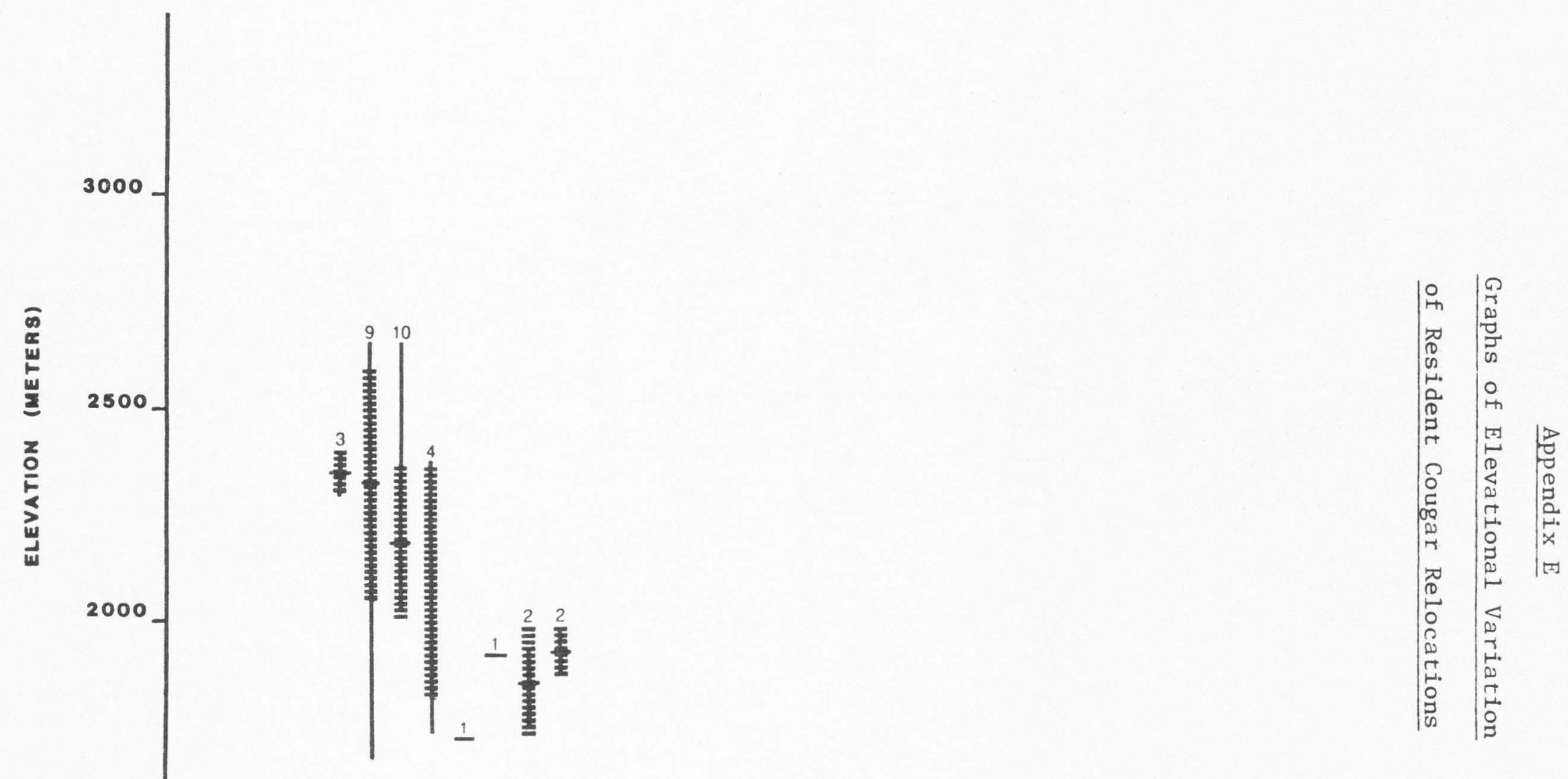

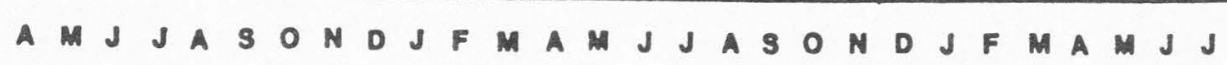

1878

1980

1981

Figure 13. Monthly mean elevation (m) including range and standard deviation for resident female cougar F80 on the Boulder-Escalante study area, Utah, 1979-1980. 


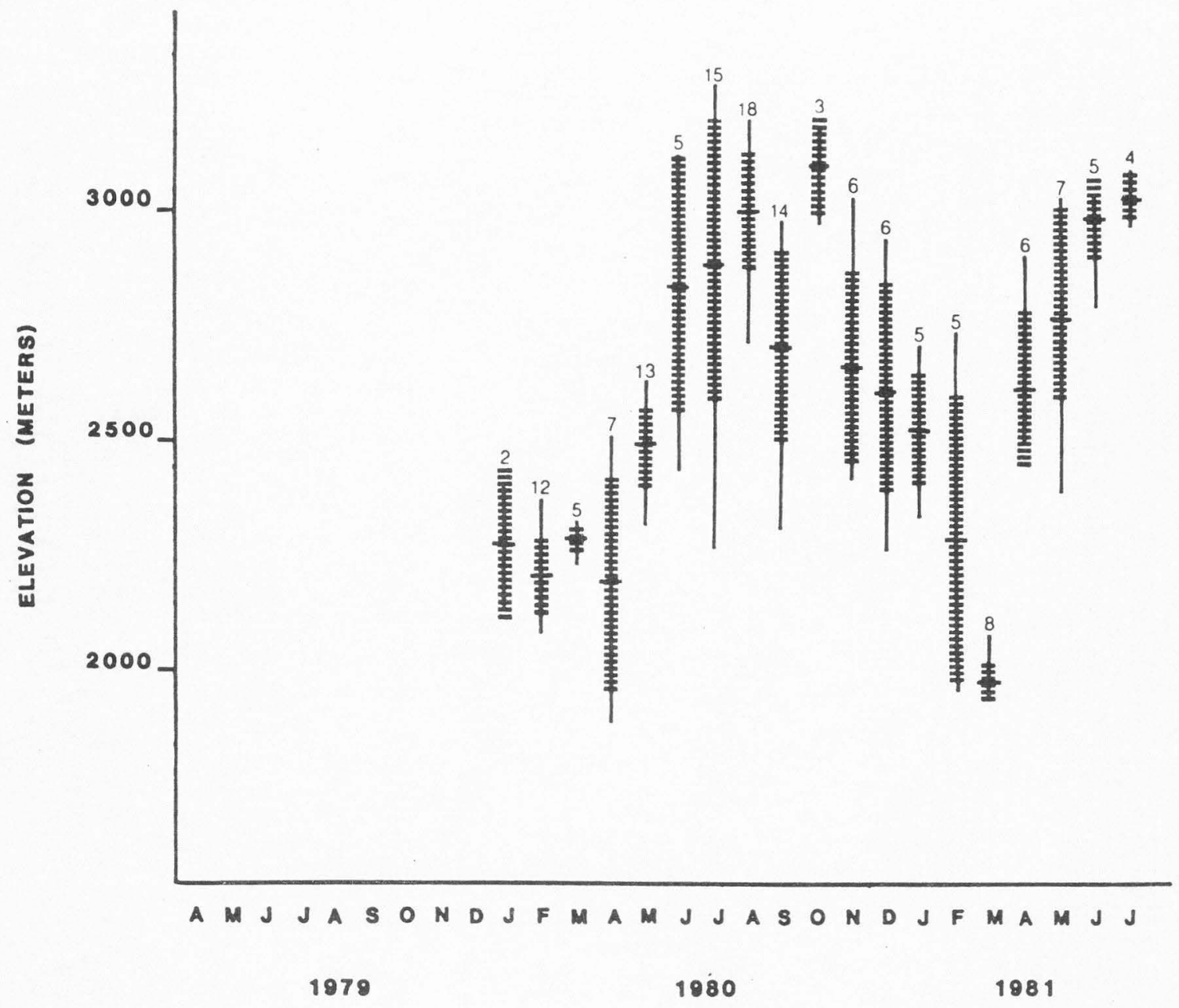

Figure 14. Monthly mean elevation (m) including range and standard deviation for resident female cougar F90 on the Boulder-Escalante study area, Utah, 1980-1981. 


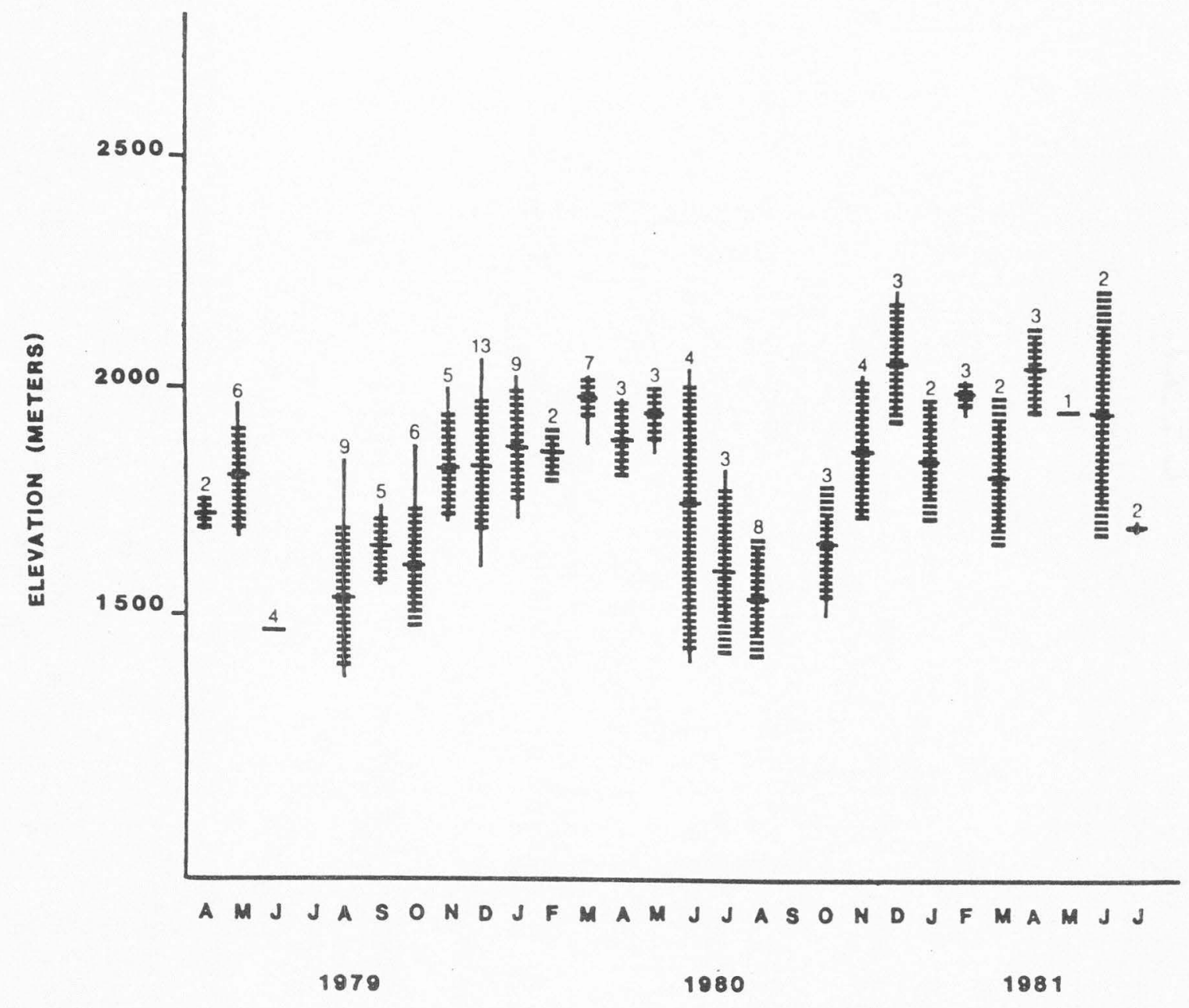

Figure 15. Monthly mean elevation (m) including range and standard deviation for resident female cougar F130 on the Boulder-Escalante study area, Utah, 1979-1981. 


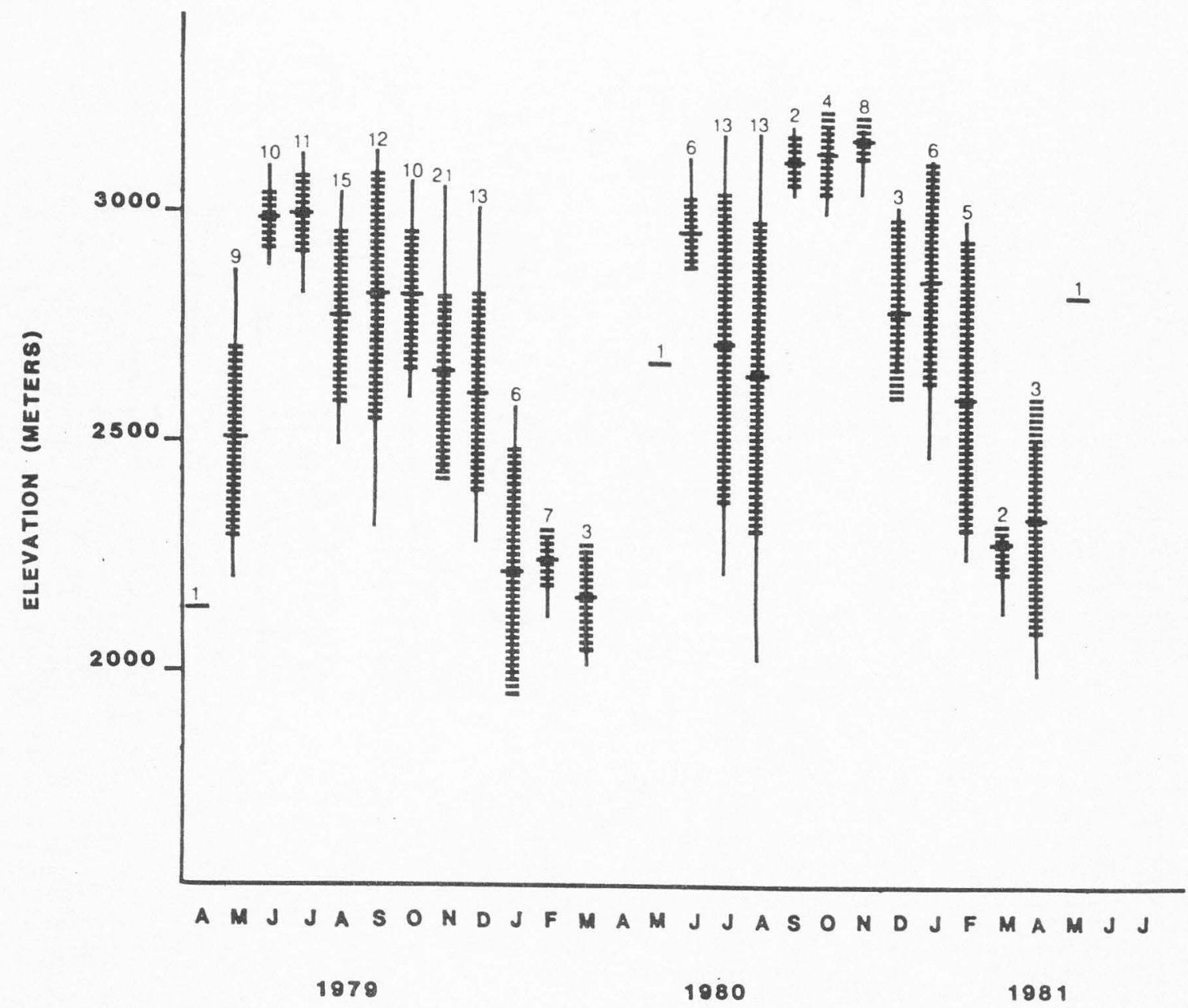

Figure 16. Monthly mean elevation (m) including range and standard deviation for resident female cougar F150 on the Boulder-Escalante study area, Utah, 1979-1981. 


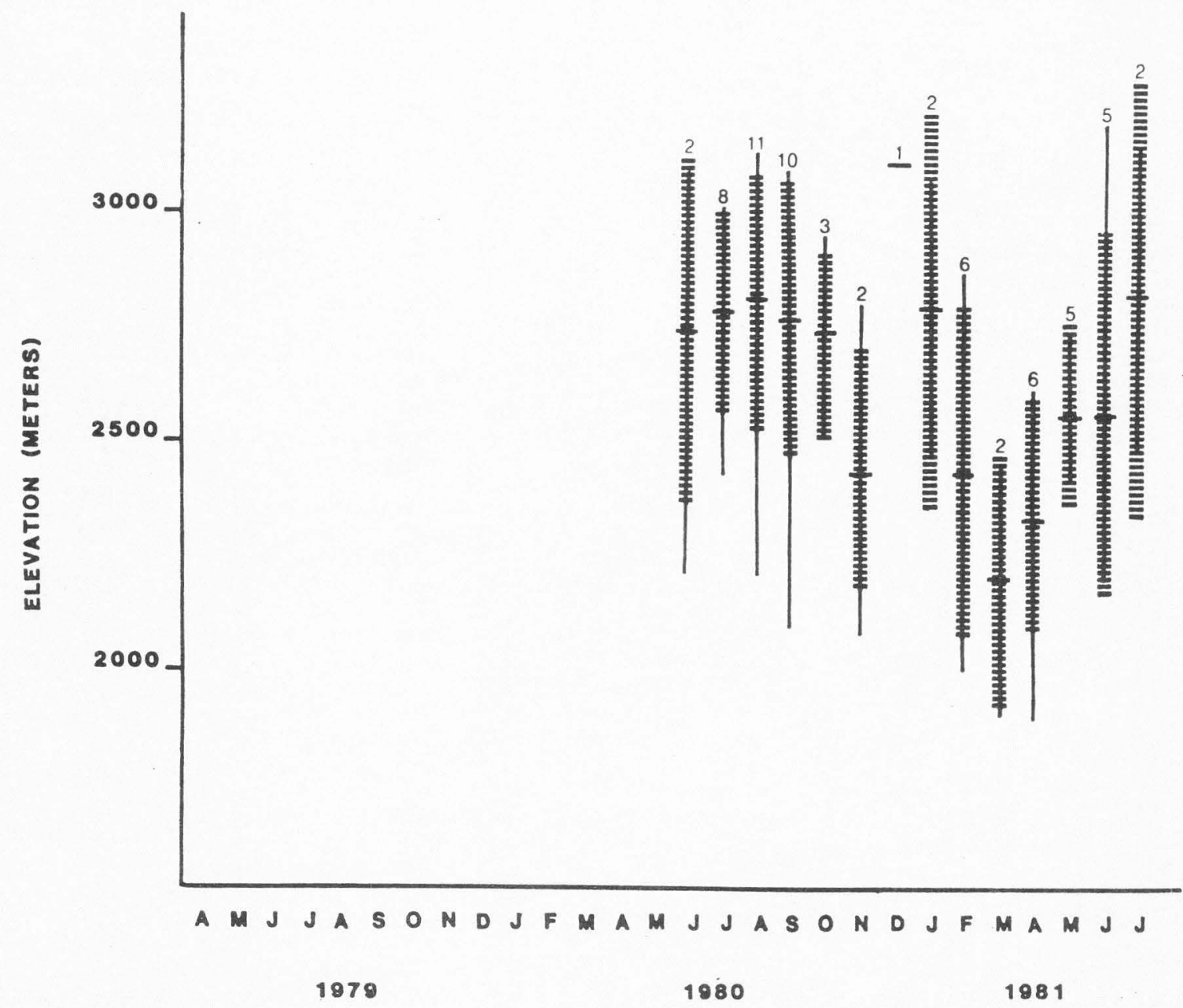

Figure 17. Monthly mean elevation (m) including range and standard deviation for resident male cougar M180 on the Boulder-Escalante study area, Utah, 1980-1981. 
Table 9. Details of nine dead cougars found on the Boulder-Escalante study area, April 1979 to July 1981.

\begin{tabular}{|c|c|c|c|c|}
\hline \multicolumn{2}{|c|}{ Date found } & \multirow{2}{*}{$\begin{array}{c}\text { Location found } \\
\text { Steep Creek Bench }\end{array}$} & Age & \multirow[t]{2}{*}{ Remarks } \\
\hline 22 & Apr 1979 & & $3-4$ yr & \\
\hline & Apr 1979 & King Bench & $<2$ mo & Almost completely consumed. \\
\hline 25 & Nov 1979 & E of Roundup Mdw & $5-6$ yr & $\begin{array}{l}\text { Skeleton only. Probably died before } \\
\text { study began. }\end{array}$ \\
\hline 6 & Feb 1980 & Bailey Wash & $4 \mathrm{mo}$ & Complete1y consumed by other cougars. \\
\hline 7 & Jun 1980 & Varney-Griffin Hole & $1.5 \mathrm{yr}$ & $\begin{array}{l}\text { Killed, eaten, and cached by another } \\
\text { cougar. }\end{array}$ \\
\hline & Jun 1980 & NE of White's Creek & 2 yr & Dead of unknown causes. \\
\hline 12 & May 1981 & Bear Creek & $7 \mathrm{mo}$ & C151 found dead and mostly consumed. \\
\hline 3 & Jun 1981 & $\mathrm{~N}$ of Escalante & $15 \mathrm{mo}$ & $\begin{array}{l}\text { Found dead near 1ivestock yard. Died } \\
\text { winter } 1981 \text {. }\end{array}$ \\
\hline 9 & Jun 1981 & Posy Lake & $8 \mathrm{mo}$ & Found shot near road. \\
\hline
\end{tabular}




\section{Appendix G}

Male Scratch and Female Scat Mound Data Summary

Data were gathered throughout the study on scratches made by male cougars and scat mounds made by female cougars (Tab1e 10). Although only one male cougar was present during most of the study, detailed data were gathered on 59 scratches observed during other study activities. Data on 22 female scat mounds were also recorded.

Thirty additional scratches were observed on transects conducted during August and September 1980 in spruce-aspen vegetation at about 2500 to $3000 \mathrm{~m}$ in elevation. Transects were established to develop a relative index of scratch density in different topographic types. Establishment of transects included methods not mentioned in the Methods section. The observer began at a location on a topographical map, and followed a predetermined compass bearing. Three parallel transects, each 1 mile long, and 10 paces apart were delineated at each site. At ten locations on the transect 20 trees were sampled. The first 20 trees encountered on a 5 meter strip perpendicular to, and on alternating sides of the center line, were classified as to species, $\mathrm{DBH}$, and dominance class as described in the Methods section. 
Table 10. Variables associated with scratches and female scat mounds observed on the Boulder-Escalante study area, Utah, 1979-1981.

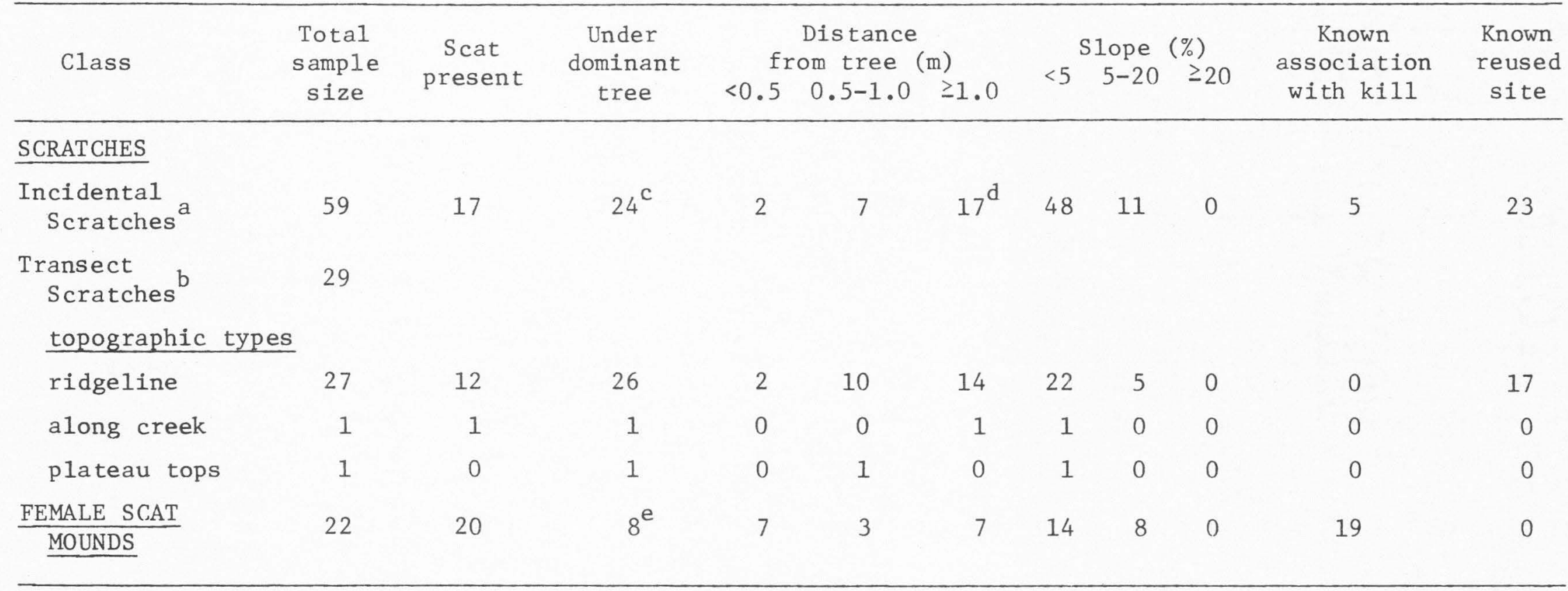

${ }^{a}$ Scratches observed incidentally to other study activities.

${ }^{b}$ Scratches observed on transects conducted.

${ }^{c}$ Sample size in this category $=29$.

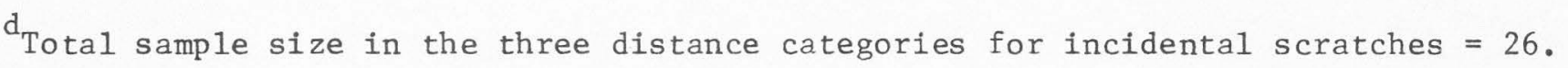

$\mathrm{e}_{\text {Sample size in this }}$ category $=11$. 

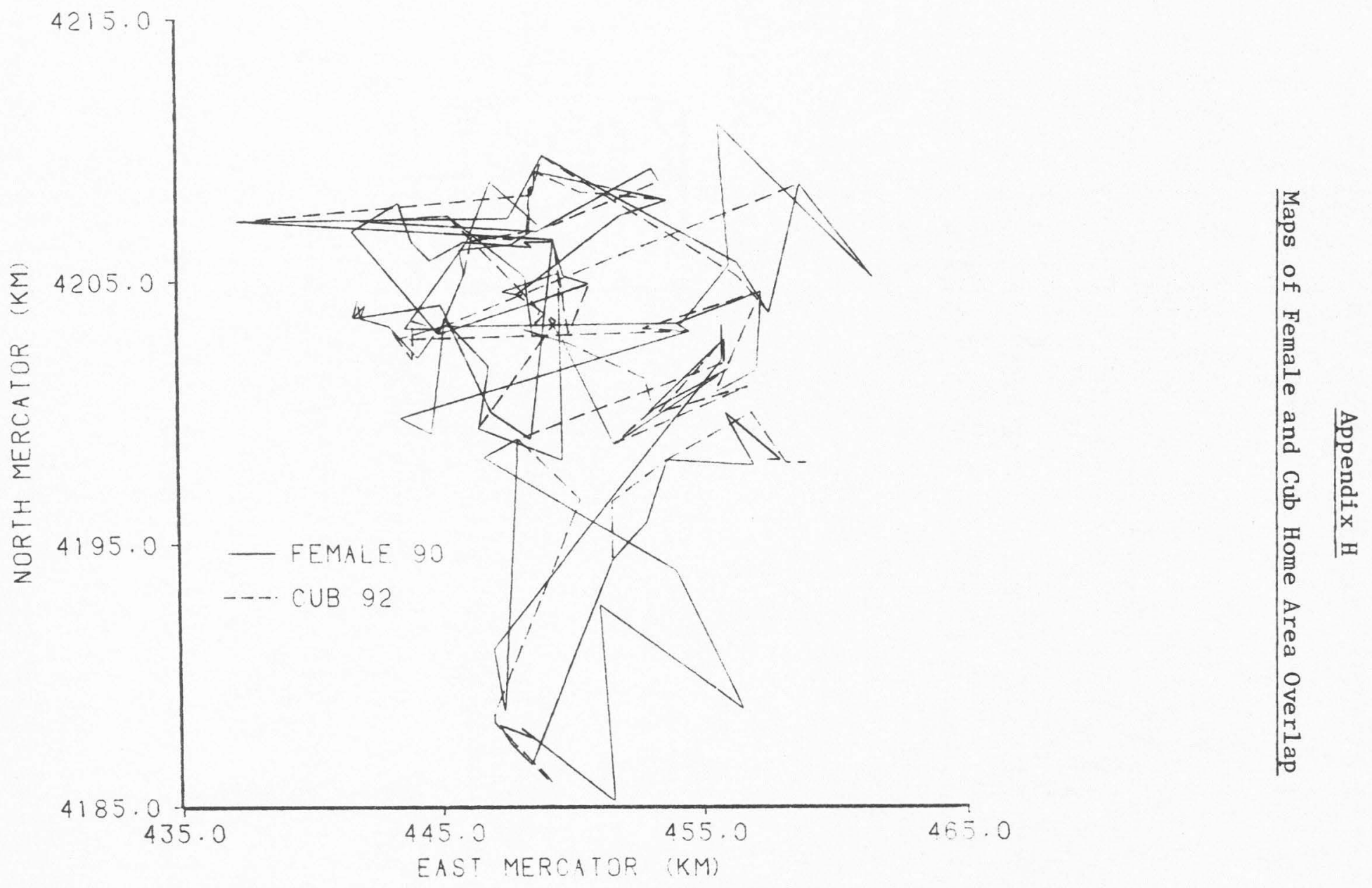

Fig. 18. Home area overlap of resident female F90 and her female cub FC 92 on the Boulder-Escalante study area, Utah, 15 February 1980 to 19 January 1981. 


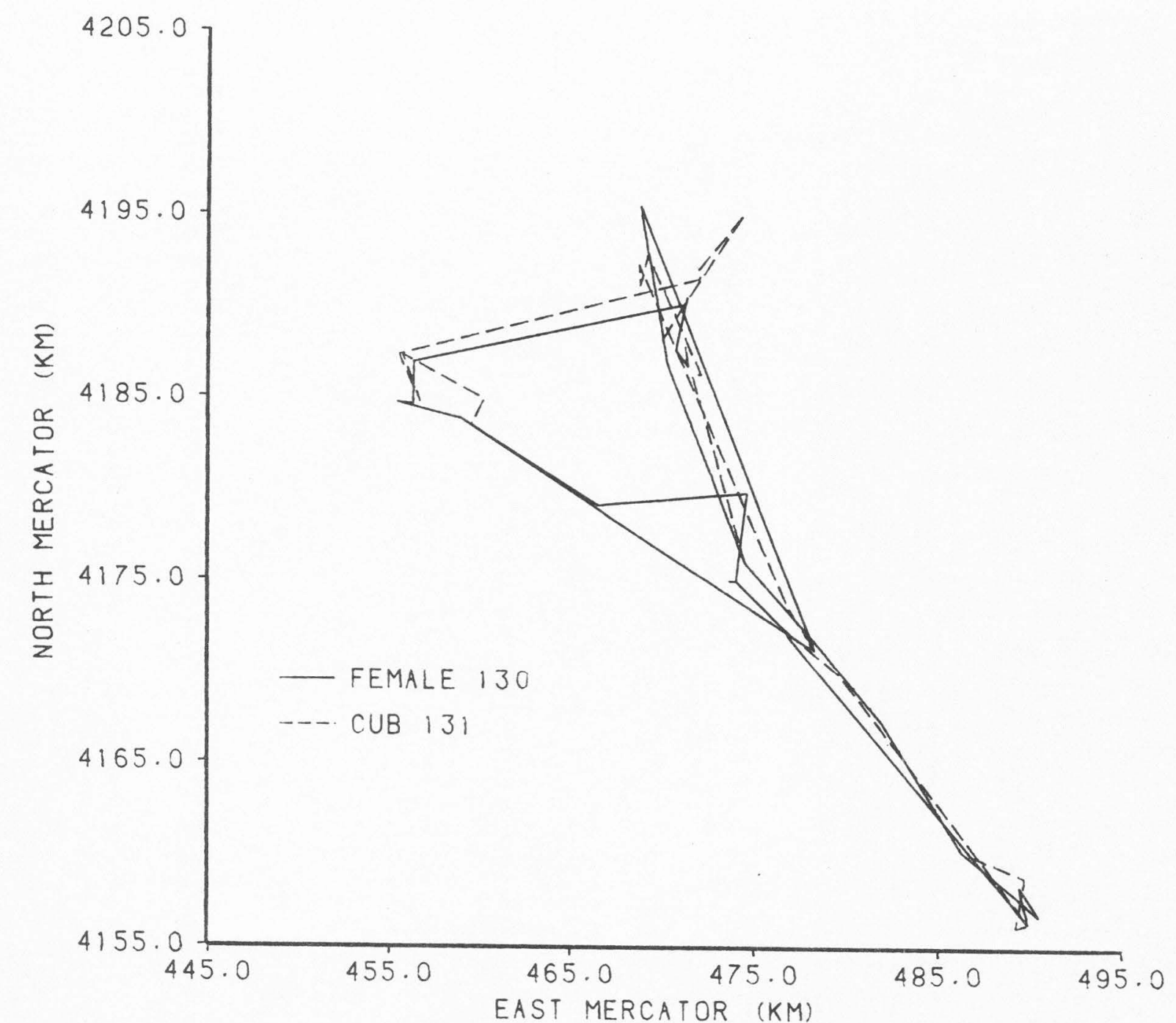

Fig. 19. Home area overlap of resident female F130 and her male cub MC 131 on the Boulder-Escalante study area, Utah, 22 April 1979 to 6 September 1979. 


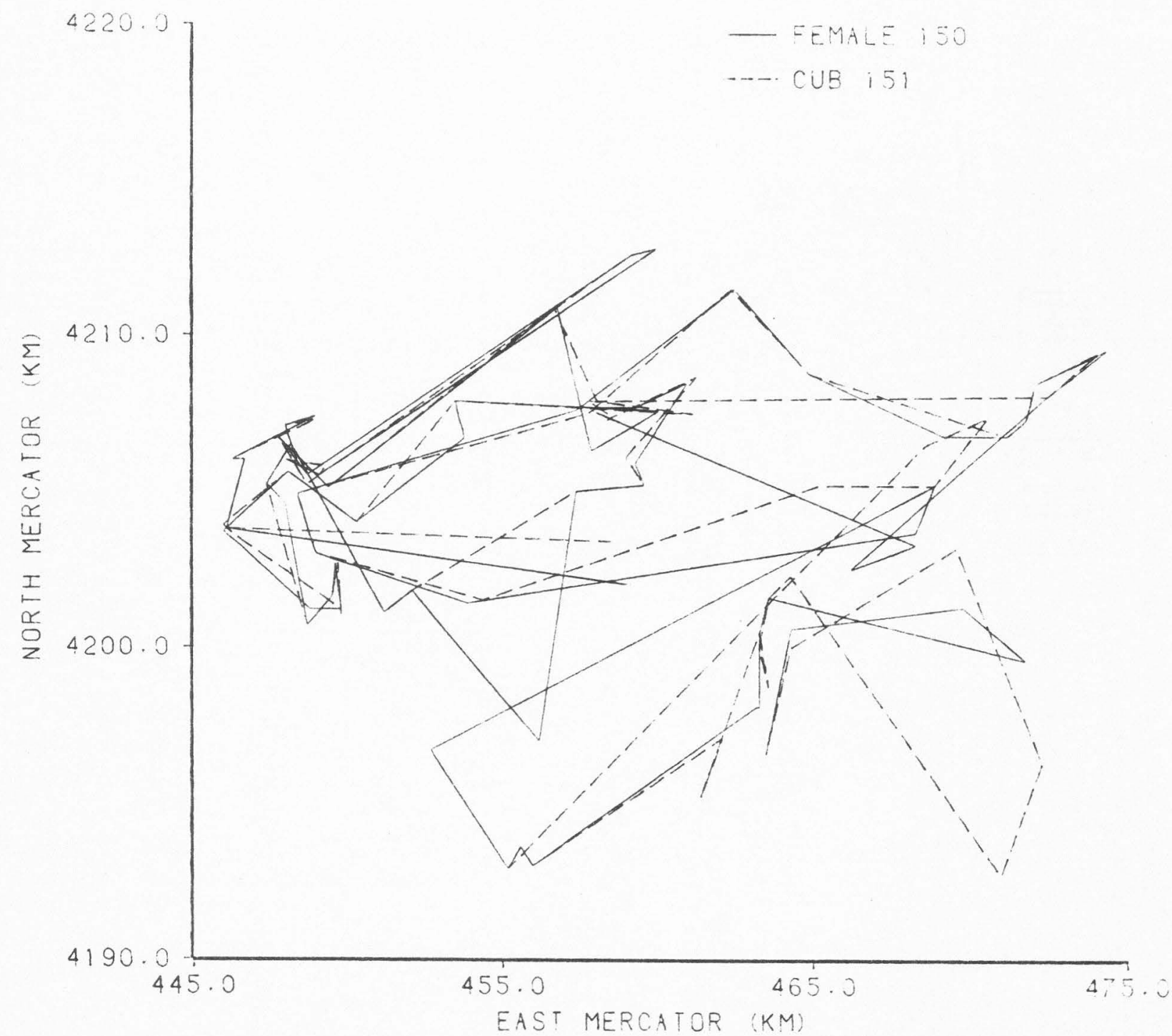

Fig. 20. Home area overlap of resident female F150 and her female cub FC 151 on the Boulder-Escalante study area, Utah, 7 September 1979 to 30 March 1980. 